\title{
Late Neogene and Quaternary lagomorphs from Tuscany: a revision based on specimens in Basel Naturhistorisches Museum and Florence University collections
}

\author{
Chiara Angelone • Lorenzo Rook
}

Received: 3 October 2011/ Accepted: 30 November 2011 / Published online: 6 January 2012

(C) Akademie der Naturwissenschaften Schweiz (SCNAT) 2011

\begin{abstract}
A revision of the Late Turolian (Messinian)Biharian (Early Pleistocene) lagomorphs from Tuscany kept in the collections of the Basel Naturhistorisches Museum is the basis for increasing our knowledge on the Late Neogene and Quaternary Italian lagomorph record. The study of the NMB collection has been combined with a revision of coeval Tuscan lagomorphs recorded in the collections of the University of Florence. The taxa herein studied and described represent three leporids (Alilepus meini from the Early Messinian of Baccinello V3, Trischizolagus sp. from the latest Messinian of Borro Strolla, and Oryctolagus valdarnensis from the Early Pleistocene of Upper Valdarno) and two ochotonids (Prolagus cf. sorbinii from the Early Messinian of Velona and the latest Messinian to earliest Pliocene of Borro Strolla, and Prolagus aff. sorbinii from the Late Pliocene of Arcille and the Early Pleistocene of Upper Valdarno). The taxonomic study is completed with notes on evolutionary tendencies and palaeobiogeography of the studied species.
\end{abstract}

Keywords Lagomorpha - Taxonomy · Evolutionary/phylogenetic tendencies . Palaeobiogeography · Peninsular Italy . Late Neogene · Early Pleistocene

\footnotetext{
C. Angelone

Dipartimento di Scienze Geologiche, Università Roma Tre, Largo San Leonardo Murialdo 1, 00146 Rome, Italy

e-mail: angelone@uniroma3.it

L. Rook ( $\square)$

Dipartimento di Scienze della Terra, Università di Firenze,

Via La Pira 4, 50121 Florence, Italy

e-mail: lorenzo.rook@unifi.it
}

\author{
Abbreviations \\ FU Faunal Unit \\ NMB Basel Naturhistorisches Museums \\ IGF "Museo di Storia Naturale" (Geology and \\ Palaeontology Section) of the University \\ of Florence \\ $L \quad$ Length \\ W Width \\ PH Hypoflexus depth \\ AA Partial width (sensu Angelone and Sesé 2009) \\ Ltrig Trigonid length \\ Ltal Talonid length \\ Wtrig Trigonid width \\ Wtal Talonid width
}

\section{Introduction}

This paper offers a synthetic overview of the lagomorph record in the Late Neogene and Quaternary of Tuscany. This paper was conceived after the revision of material kept in the collections of the Basel Naturhistorisches Museum. Given Burkart Engesser's recognized outstanding expertise in rodents, at first glance the reader could be surprised to find a paper dealing with lagomorphs in the frame of this volume. As a matter of fact, as field paleontologist, an important contribution of Burkart Engesser is the survey and documentation of the Late Miocene mammal-bearing localities of the Baccinello Basin in southern Tuscany (Hürzeler and Engesser 1976; Engesser 1983, 1989, 2000; Rook et al. 1996, 1999). His interest in fossiliferous localities in Italy is grounded not only on the steps of his professor, the late Prof. Johannes Hürzeler (1908-1995), but is actually framed into a long-lasting 
interest of Basel palaeontologists on the vertebrate fossil record of Tuscany.

On the occasion of a recent visit to the NMB, we had opportunity to study the Late Neogene and Quaternary record of Italian lagomorphs in the Basel collections and we found out that the Italian record of lagomorph was in deep need of a revision. A detailed study of such material has never been accomplished and the available descriptions are not adequate to present-day understanding of the evolutionary history of these taxa. The same was true for part of the lagomorph fossil record in the collections of the Florence University. Thus we are taking this opportunity for preparing a comprehensive review. All the studied material comes from fossiliferous localities of Tuscany, Italy (Fig. 1). The studied taxa are:

- two species of the ochotonid Prolagus. One species from the Early Messinian of Velona and the latest Messinian to earliest Pliocene of Borro Strolla; the other from the Late Pliocene (Early Villányian; MN16a) of Arcille and from the Early Pleistocene (latest Villányian-earliest Biharian) of Upper Valdarno (Olivola and Tasso Faunal Units);

- the latest Miocene leporid Alilepus from Baccinello V3 (MN 13);

- the leporid Trischizolagus from the latest Messinian of Borro Strolla;

- the leporid Oryctolagus from the Early Pleistocene (Early Biharian) of Upper Valdarno (Tasso Faunal Unit).

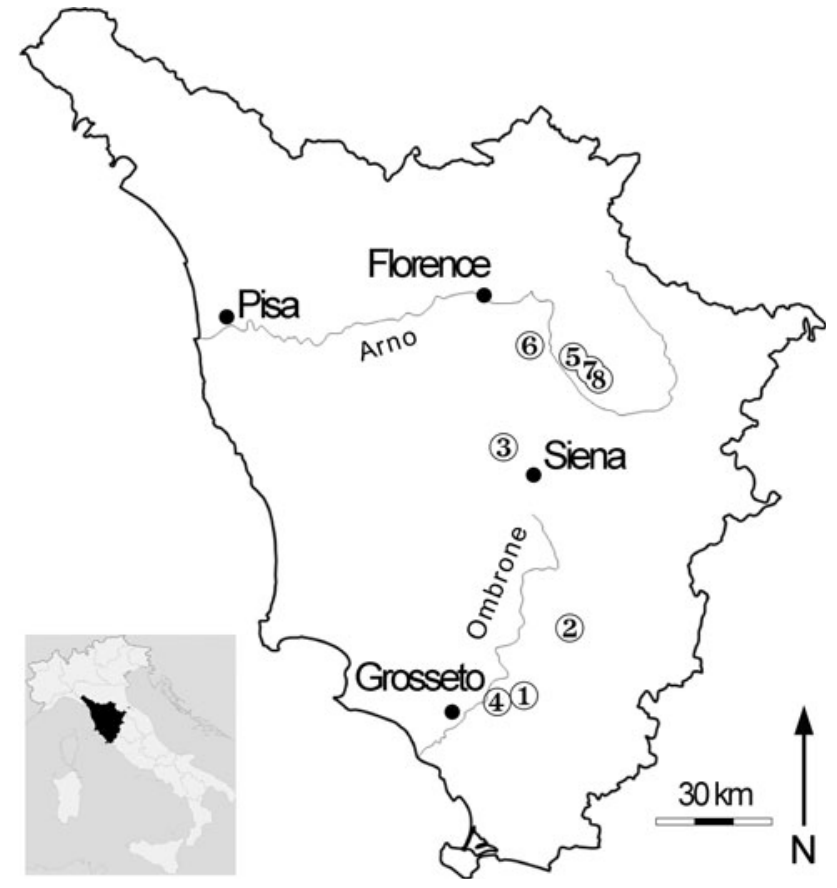

Fig. 1 Location map of studied lagomorph-bearing localities from Tuscany recorded in the NMB and the IGF. 1 Baccinello V3, 2 Velona, 3 Borro Strolla, 4 Arcille, 5-8 Upper Valdarno (5 Solava, 6 Castello Incisa, 7 Case Inferno, 8 Strette al Tasso)
Also available for study was the Late Miocene insular endemic ochotonid Paludotona from Baccinello (V0-V2). However, Paludotona, due to its unresolved phylogenetic origins and the temporal and palaeobiogeographical problems related to its arrival on the Tusco-Sardinian palaeobioprovince, deserves to be the subject of a separate paper.

\section{Materials and methods}

The studied material consists of upper and lower jaws and isolated teeth. It is housed in the Basel Naturhistorisches Museums and in the Natural History Museum (Geology and Palaeontology Section) of the University of Florence. The list of additional material from other institutions assigned to the species here reviewed is reported in Appendix 1.

The occlusal surface of each tooth was drawn using a camera lucida mounted on a Leica MS5 binocular microscope. SEM images were performed for unworn, problematic or very damaged individuals. Occlusal measurements were taken from the drawings. The measurements introduced for ochotonids by Angelone and Sesé (2009) are here used also for leporid teeth (see Angelone and Rook 2011). The nomenclature (Fig. 2) follows Angelone and Sesé (2009) for ochotonids and López Martínez et al. (2007) integrated with Palacios and López Martínez (1980) for leporids.

For biochronological references we follow Sala and Masini (2007) and Rook and Martínez-Navarro (2010). Although still contested within the Quaternarist community (cfr. Van Couvering et al. 2009; McGowran et al. 2009), we follow here the recent formal IUGS recognition (June 2009) of Quaternary as a Period/System with the re-designation of the base of the Pleistocene Series/Epoch in the 2.59 Ma GSSP of the Gelasian Stage.

\section{Fossil localities: geological setting and age attribution}

Latest Turolian (latest Miocene)

\section{Baccinello V3}

The geology and palaeontology of the Baccinello area (Grosseto district) are well known thanks to the early research led by J. Hürzeler (1908-1995) from the NMB (De Terra 1956; Gillet et al. 1965; Lorenz 1968), which recovered abundant faunal remains from well-documented stratigraphic levels (Hürzeler and Engesser 1976).

The Baccinello Basin records a continental sedimentation throughout the late Tortonian-Messinian. Fossiliferous deposits in the different units recognized within the Basin 


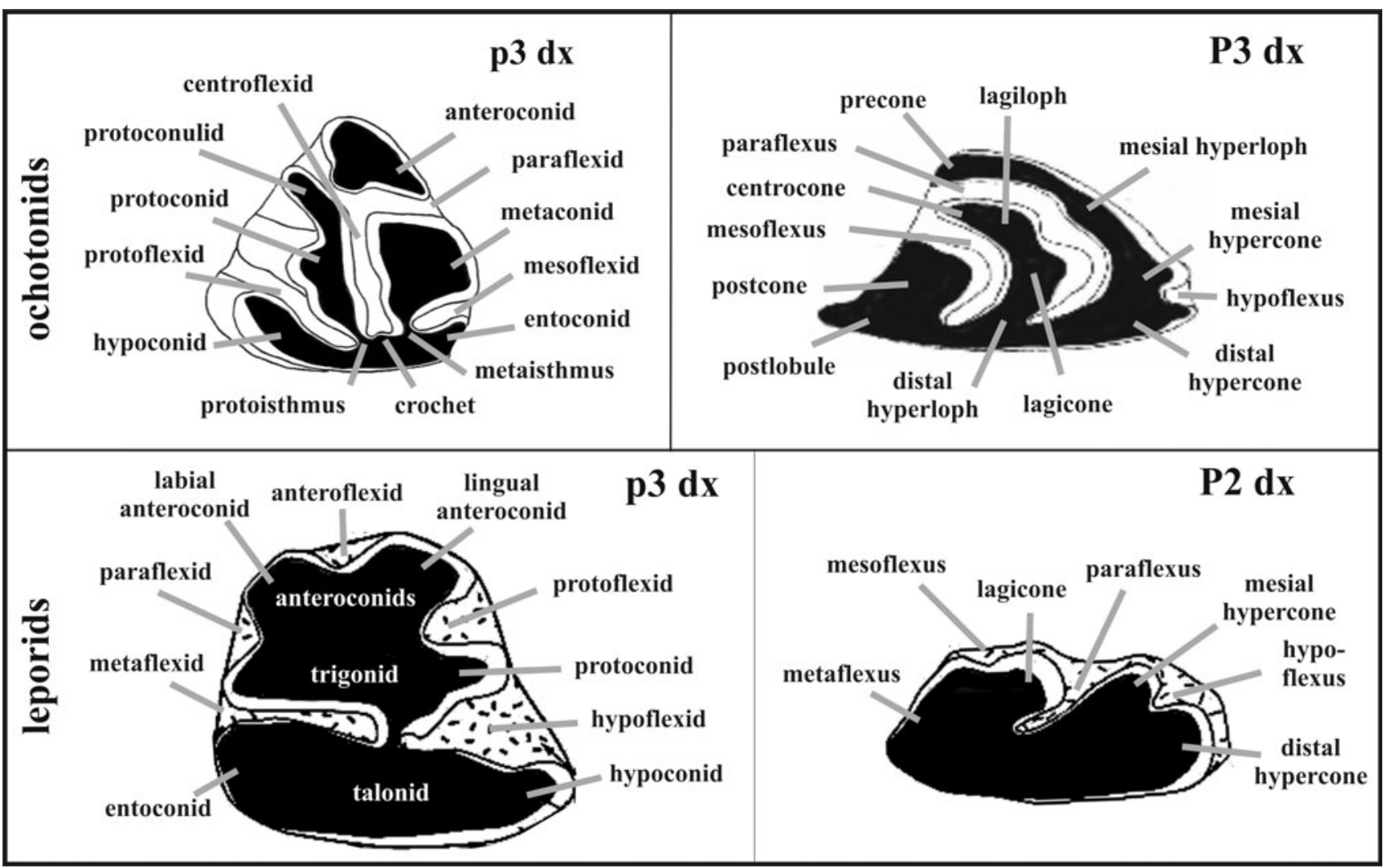

Fig. 2 Nomenclatorial synopsis. Ochotonids from Angelone and Sesé (2009); leporids from Palacios and López Martínez (1980) integrated with López Martínez et al. (2007)

(Lorenz 1968; Benvenuti et al. 2001) bear relatively abundant fossil mammal remains that are grouped into distinct assemblages (vertebrate assemblages V0, V1, V2, and V3; Lorenz 1968; Rook et al. 1996, 1999, 2000). Early Pliocene marine deposits, ascribed to the Sphaeroidinellopsis Zone, unconformably overlie the Late Miocene sedimentary succession (Bossio et al. 1991; Benvenuti et al. 2001). Rook et al. (2011) provided a synthesis of the Baccinello geological setting, and support the chronological range of the depositional history of the sedimentary succession based on a well-resolved magnetostratigraphic study, where the Baccinello V3 fauna is correlated to Chron C3An, Early Messinian, ca. 6.733-6.436 Ma (Mammal zone MN13). Leporid remains (since Hürzeler and Engesser 1976 on, see synonymic list) and a Prolagus (B. Engesser pers. com. in Rook and Masini 1990) were reported from Baccinello V3 but never described.

\section{Velona Basin}

The Velona Basin is located in southern Tuscany, about $40 \mathrm{~km}$ south of Siena. It is a small Basin (approx. $5 \mathrm{~km}$ long and $4 \mathrm{~km}$ wide), characterized by a 250 -m-thick succession, dominated by continental terrigenous sediments, and made up by two main synthems separated by an angular unconformity (Rook and Ghetti 1997; Ghetti et al. 2002). The lower synthem can be subdivided into six concordant fluvio-lacustrine subunits, interpreted as Early Messinian ('pre-evaporitic') in age (Rook and Ghetti 1997; Ghetti et al. 2002). The upper synthem has a very limited extension and is composed only by alluvial conglomerates, interpreted as the last stage of deposition of the Basin. No element exists to determine the age of these coarse deposits and they may be referred to the top of the Messinian or, at least, to the very Early Pliocene (Martini and Sagri 1993; Ghetti et al. 2002).

The small mammal fauna recovered from the fluviolacustrine subunit of the lower synthem of this Basin (Rook and Ghetti 1997; Ghetti et al. 2002) refers to the Late Miocene, bearing no evidence of the endemic Late Miocene "Oreopithecus" faunas (OZF in Bernor et al. 2001) common in other nearby basins in southern Tuscany (cfr. the Baccinello-Cinigiano Basin). This fact leads to consider the beginning of sedimentation in the Velona Basin to be more recent than in other contiguous basins (Rook and Ghetti 1997; Ghetti et al. 2002). 


\section{Borro Strolla}

The Borro Strolla area is located in the southeastern end of the Valdelsa Basin. The latter is a $25 \mathrm{~km}$ wide and $60 \mathrm{~km}$ long, located about $45 \mathrm{~km}$ SE of Florence, and is filled with more than 2,000 m of Neogene and Quaternary sediments. From a stratigraphic point of view the Neogene sediments exposed in the Valdelsa Basin, mostly of Pliocene age, have been included in a stratigraphic framework based on unconformity-bounded units (Benvenuti and Degli Innocenti 2001). In the Borro Strolla valley a succession including the Miocene-Pliocene transition has been described by Bossio et al. (2001) and, according to the recent revisions by Benvenuti and Degli Innocenti (2001) and Abbazzi et al. (2008), sediment outcroppings in the area of Borro Strolla may represent part of the oldest basin infill (Borro Strolla synthem) within the Valdelsa Basin latest Miocene-Pliocene succession. Late Miocene sediments, unconformably overlain by the Pliocene succession, crop out to a limited extent in other nearby Valdelsa Basin area, and are widely exposed in the so-called Casino Basin (Lazzarotto and Sandrelli 1977; Bossio et al. 2001; Rook et al. 2008). The field recognition of unconformities or inferences on unconformable transitions supported by facies relations and biochronologic considerations allowed Abbazzi et al. (2008) to subdivide uppermost Messinianearliest Zanclean deposits into three unconformity-bounded units consisting of various lithofacies associations indicative of different palaeoenvironments developed in this area at the Mio-Pliocene transition.

A small sample of fossil mammals has been recovered at Borro Strolla from sub-synthem BS-1 (chronologically interpreted as latest Messinian in age), while only one specimen of Prolagus has been recovered from the following sub-synthem BS-2 (interpreted as representing the Messinian-Zancelan transition) (Abbazzi et al. 2008). From sub-synthem BS-1, at least 12 taxa are documented. The large mammal assemblage includes two bovids (the mid-sized spiral-horned Samotragus sp., and a larger bovid determined as Palaeoryx-Protoryx group), a large-sized giraffid, and the cervid Paracervulus. Small mammals include the insectivore Galerix aff. depereti, six rodents (Apocricetus barrierei, Apodemus cf. gudrunae, Stephanomys aff. donnezani, Centralomys benericettii, Debruijnimys sp. and Sciuridae indet.), the ochotonid Prolagus and a leporid (Abbazzi et al. 2008). The Borro Strolla mammal assemblage suggests palaeobiogeographic connections with western Europe, fitting the general aspect of a fauna at the Mio-Pliocene boundary. The co-occurrence of terrestrial molluscs from the same sediments with a Pliocene affinity, offers further biochronologic constrains supporting the calibration of the Borro Strolla fluvial deposits to the latest Messinian-earliest Zanclean.
Early Villányian (Late Pliocene)

\section{Arcille}

"Fosso di Puntolungo" (known in literature as Arcille, from the name of the nearby hamlet) is the youngest fossiliferous locality in the area of the Baccinello Basin (Grosseto district). The fossiliferous sediments are levels of lignitic shale interbedded within the Pliocene marine deposits that unconformably overlie the Late Miocene continental deposits of the Baccinello V0-V3 sedimentary succession. Arcille yielded a small mammal assemblage first reported by Hürzeler and Engesser (1976) on the basis of material excavated by J. Hürzeler in 1954 during one of his first surveys in the Baccinello area. The small mammal assemblage includes the vole Mimomys hassiacus (Masini and Torre 1987) and can be referred to the Mimomys hajnackensis zone of the Early Villányian.

Arcille represents one of the few known Early Villányian assemblages of Italy (Sala and Masini 2007), together with the rich faunal assemblages of Cascina Arondelli in the area of Villafranca d'Asti in Piedmont (Berzi et al. 1967; Fejfar 2001) and San Giusto from the Lower Valdarno in Tuscany (the type locality for Mimomys stehlini; Forsyth Major 1902; Masini and Torre 1987). These faunas are coeval with the Early Villafranchian large mammal assemblages of the Triversa Faunal Unit (Maul et al. 1998; Rook and Martínez-Navarro 2010) and correlated to the Gauss Magnetochron, below the top of the Kaena event (C2An.2-C2An.1) with an inferred geochronometric age of 3.60-3.10 Ma (Napoleone et al. 2003). Hürzeler and Engesser (1976) mentioned the occurrence of Prolagus in the Arcille faunal list, but a description of the material was never provided.

\section{Late Villányian/Early Biharian (Early Pleistocene)}

\section{Upper Valdarno Basin}

The lagomorph record from Upper Valdarno is known since early papers (Falconer 1865, 1868; Bosco 1899a, b). The revision of this material faces the problem that often occurs when revising material from historical collection. In most cases in fact, there is no indication of the exact provenance of the specimens and the labels just reports "Upper Valdarno". When the topographic indication is given, in most cases it is possible to establish, at least with some approximation, the general stratigraphic unit of provenance.

The Upper Valdarno record is celebrated for the wellknown large mammal collections, whereas the small mammals have a documentation that is not even comparable with that of large mammals (Cioppi and Dominici 
2011; Rook et al. 2012). Despite the scanty record of small mammals the lower portion of the second sedimentary phase of the Basin infilling (the Montevarchi synthem) yielded a few vole remains that allowed to identify the Mimomys polonicus zone (Late Villányian, earliest Pleistocene) in sediments characterized by reversed magnetization, referred to the pre-Reunion interval of the Matuyama Chron (Napoleone et al. 2003; Ghinassi et al. 2004, 2005).

In the upper part of the same sedimentary complex (the Montevarchi synthem) is located the Castelfranco di Sopra site. The latter is the type locality of Mimomys pliocaenicus, the vole that defines the homonymous zone of the Late Villányian (Early Pleistocene; Masini and Torre 1987). Several local faunas bearing large mammals, grouped in the Olivola FU, are indirectly referred to the M. pliocaenicus zone (Torre et al. 1996, 2001). The sediment outcroppings in these localities are directly correlated with the interval between Reunion and early part of Olduvai Subchrons (Napoleone et al. 2003).

The uppermost portion of the sedimentary complex belonging to the Montevarchi synthem yielded abundant large mammals typical of the Tasso FU. The transition from the Olivola FU to the subsequent Tasso FU (within the Late Villafranchian) is accomplished mainly by dispersal events (Torre et al. 1992, 2001), which succeeded in a time span that has been magnetostratigraphically calibrated close to the top of the Olduvai Subchron (Napoleone et al. 2003). It thus corresponds to the mid part of Early Pleistocene (or the former Pliocene-Pleistocene boundary) at the Gelasian/Calabrian boundary as defined at the La Vrica section (Aguirre and Pasini 1985; Albianelli et al. 2002). The transition between Olivola and Tasso FUs is thus placed within an interval of gradual climatic transition, which mirrors the gradual change in large mammals faunal composition (Rook and Martínez-Navarro 2010). Few remains of Mimomys savini came from these Upper Valdarno localities: Case Inferno and Le Strette (Torre 1985), that allow recognizing the occurrence of Early Biharian small mammal assemblage within the Tasso FU (Sala and Masini 2007).

Rook and Masini (1990) reported the occurrence of the ochotonid Prolagus both in the Late Villányian (a fragmentary mandible from Solava) and in the Early Biharian (a fragmentary mandible from Case Inferno). The site of Solava is located near Figline Valdarno and is correlatable with the site of Poggio Rosso, Olivola FU (Napoleone et al., 2001), whereas Case Inferno (in literature also referred to as "Inferno", or "L'Inferno"), one of the most celebrated sites of the Tasso FU, yielded Mimomys savini remains and it is thus correlatable to the Early Biharian.

\section{Systematic palaeontology}

Order Lagomorpha Brandt, 1855

Family Ochotonidae Thomas, 1897

Genus Prolagus Pomel, 1852

Prolagus cf. sorbinii Masini, 1989

Figure $3 \mathrm{a}-1$, measures in Table 1

1997 Prolagus ex gr. sorbini-michauxi Rook and Ghetti, p. 341,343 ; p. 344 , fig. $4 a-d$.

2002 Prolagus ex gr. sorbini-michauxi Ghetti et al., p. 8, tab. 2; p. 16.

2007 Prolagus cf. P. sorbinii Angelone, p. 411, fig. 4a-d; p. 412 , tab. 1 ; p. 414 text and fig. 6 ; p. 418 ; p. 419.

2008 Prolagus sorbinii Abbazzi et al., p. 620, tab. 1; p. 621 , fig. 6 h; p. 621-622.

Localities: Velona Basin and Borro Strolla (Siena).

Age: Messinian to earliest Pliocene.

Material

Velona: $\mathrm{P}^{2} \mathrm{dx}$ : IGF $9432 \mathrm{~V} ; \mathrm{P}_{3}$ sin: IGF 9433V; IGF 9434V; IGF 9435V; lower molariform IGF 9476V; $\mathrm{M}_{2}$ IGF $9477 \mathrm{~V}$.

Borro Strolla BS-1: lower jaw sin: IGF $9473 \mathrm{~V}\left(\mathrm{M}_{1}-\mathrm{M}_{2}\right.$ plus a loose $\left.\mathrm{P}_{4}\right) ; \mathrm{P}^{3} \mathrm{dx}$ : IGF $9451 \mathrm{~V} ; \mathrm{P}^{4} \mathrm{dx}$ : IGF $9452 \mathrm{~V}$; $\mathrm{M}^{1}$ sin: IGF $9453 \mathrm{~V} ; \mathrm{M}^{2}$ sin: IGF $9455 \mathrm{~V} ; \mathrm{M}^{2} \mathrm{dx}$ : IGF $9470 \mathrm{~V} ; \mathrm{D}_{3}$ sin: IGF $9456 \mathrm{~V} ; \mathrm{P}_{3}$ sin: IGF $9454 \mathrm{~V} ; \mathrm{P}_{3} \mathrm{dx}$ : IGF $9469 \mathrm{~V}$

Borro Strolla BS-2: upper jaw dx: IGF 9475V $\left(\mathrm{P}^{3}-\mathrm{M}^{2}\right)$

\section{Description}

Upper jaw: premolar foramen lying in front of $\mathrm{P}^{4}$. Each teeth position will be described in the corresponding section.

Lower jaw: foramina and other salient features are not visible in this mandible fragment. Talonids are more flattened than trigonids and bear a long isthmus.

$\mathrm{P}^{2}$ : $\left(\mathrm{P}^{2}\right.$ : (Fig. 3d) the mesial hyperloph, thin and covering almost all the centrocone is broken in its labial end, but the observation of the shaft of the tooth in its anterior part indicates that the enamel is continuous; para- and mesoflexus are verticalized in their distal end; the mesoflexus is particularly deep, almost reaching the distal edge of the tooth; the postcone is broken, and does not appear large and globous as drawn in Rook and Ghetti (1997) and Angelone (2007); the lagicone is roundish and does not bear an incipient centroloph as pictured in the two cited papers.

$\mathrm{P}^{3}$ : (Fig. 3h) quite deep hypoflexus, proximal hypercone much smaller than the distal one; mesial hyperloph 


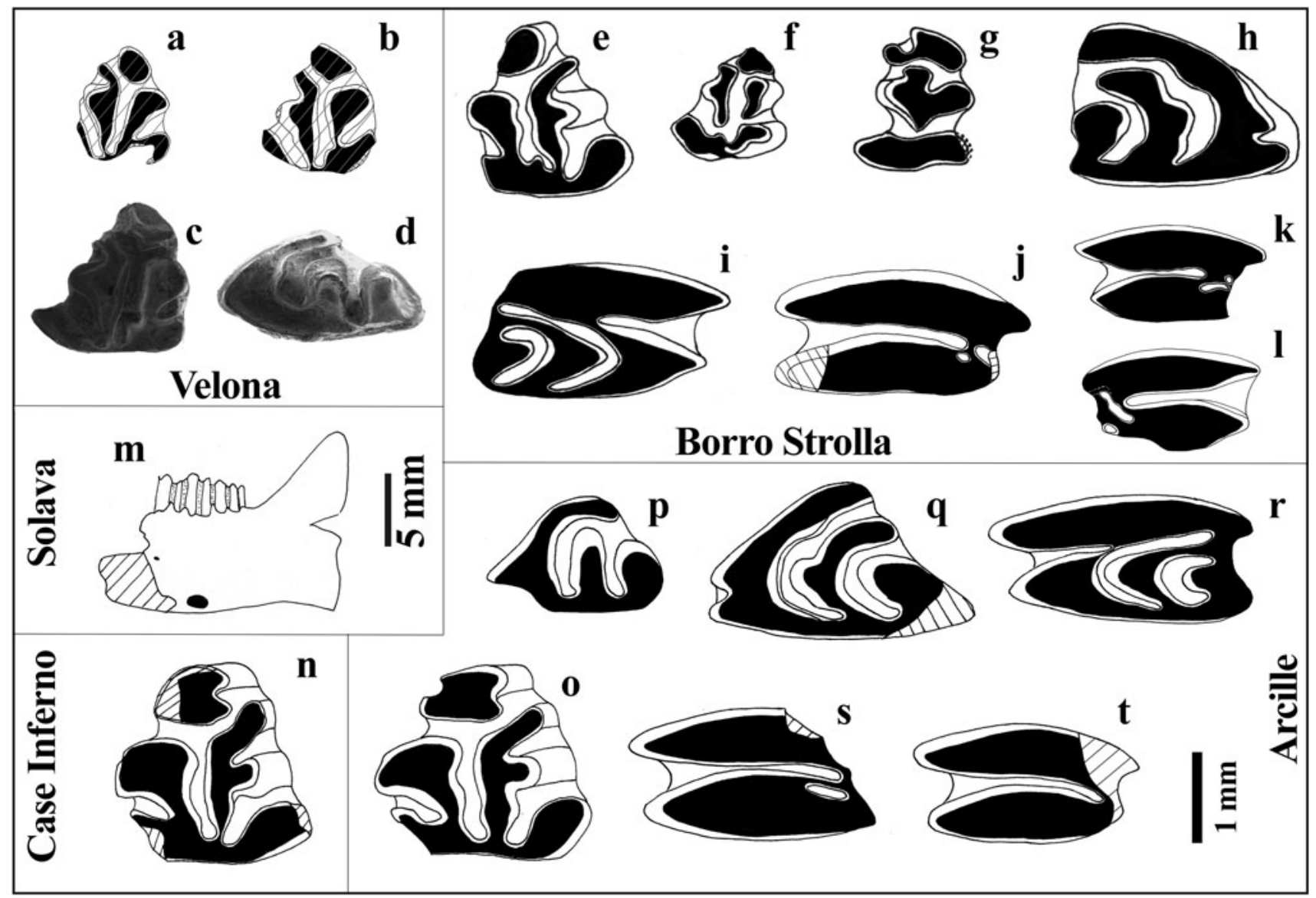

Fig. 3 Prolagus cf. sorbinii: a-c, $\mathbf{f}_{3}$ sin IGF 9433V, IGF 9434V, IGF 9435V, IGF 9469V; d P $\mathrm{P}^{2}$ dx IGF 9432V; e $\mathrm{P}_{3}$ dx IGF 9454V; g D 3 sin IGF $9456 \mathrm{~V} ; \mathbf{h} \mathrm{P}^{3} \mathrm{dx}$ IGF $9451 \mathrm{~V} ; \mathbf{i} \mathrm{P}^{4} \mathrm{dx}$ IGF $9452 \mathrm{~V} ; \mathbf{j ~ M}^{1}$ sin

narrowing in its medial part, with enamel hiatus; lagiloph not reaching the outer part of the tooth; the connection between lagicone and lagiloph is sharply indented.

$\mathrm{P}^{4}$ : (Fig. 3i) proximal hypercone slightly smaller than the distal one; $\mathrm{V}$-shaped hypoflexus not reaching the half of the tooth; parafossette long and curving upwards; C-shaped, long mesofossette.

$\mathrm{M}^{1}$ : (Fig. 3j) hypoflexus deep, very slight undulated, with small, round fossette under its labial end and another oval, slightly larger one positioned after the hypoflexus end. In the "radical" part of the tooth fossettes do not disappear with wear.

$\mathrm{M}^{2}$ : (Fig. 3k, 1) hypoflexus deep, very slightly undulated in its anterior part in IGF $9455 \mathrm{~V}$; one large, bean-like fossette lies under the distal part of its labial end and another smaller, roundish fossette positioned near the labial border at the same height of the hypoflexus; the fossettes do not disappear with wear in IGF $9455 \mathrm{~V}$, whereas in IGF $9470 \mathrm{~V}$ only one fossette is observable in "radical" side; in the less worn individual (IGF 9470V) the parafossette is very elongated labial edge.
IGF 9453V; k M ${ }^{2} \sin$ IGF 9455V; I M ${ }^{2}$ dx IGF 9470V; Prolagus aff. sorbinii: $\mathbf{m}$ lower jaw sin IGF $2827 \mathrm{~V} ; \mathbf{n}$, o $\mathrm{P}_{3} \mathrm{dx}$ NMB VA2246, NMB FP30; p-t $\mathrm{P}^{2}-\mathrm{M}^{2}$ of upper jaw sin NMB FP29

$\mathrm{D}_{3}$ : (Fig. 3g) triangular anteroconid, connected to a labial accessory cusp. The metaconid-protoconid complex is characterized by an antero-posterior indentation and it is not connected to the entoconid-hypoconid complex. The entoconid is broken in its anterior lingual part, however, the enamel seems to be continuous around its edge.

$\mathrm{P}_{3}$ : (Fig. 3a-c, e, f) the occlusal surface of two over 3 specimens from Velona (IGF $9433 \mathrm{~V}$, IGF $9435 \mathrm{~V}$ ) is very damaged. The tooth is slender $(L>W)$; in the specimens from Velona and in the juvenile unworn specimen from Borro Strolla (IGF 9454V) the anteroconid is posteriorly and/or laterally indented, whereas in the more worn specimen from Borro Strolla (IGF 9469V) its outline is smooth. The triangular metaconid is as large or slightly larger than the anteroconid. The mesoflexid is wide, V-shaped, in the specimens from Velona. The entoconid is thick, without enamel hiatus, in most cases as prominent or less prominent than the metaconid; the crochet is developed and deplaced towards the metaconid in IGF 9434V (Velona) and IGF 9469V (Borro Strolla), whereas it is extremely reduced/absent in the other two specimens from Velona. In 
Table 1 Tooth measurements (in $\mathrm{mm}$ ) of the lagomorph taxa analyzed in this paper (estimated measurements in parentheses)

\begin{tabular}{lllllll}
\hline Prolagus cf. sorbinii & $L$ & $W$ & AA & PH \\
\hline $\mathrm{P}^{2}$ & IGF 9432V & Velona & 1.25 & & & \\
$\mathrm{P}^{3}$ & IGF 9451V & Borro Strolla BS1 & 1.77 & & 2.33 & \\
$\mathrm{P}^{3}$ & IGF 9475V & Borro Strolla BS2 & 1.65 & 2.77 & 2.13 & \\
$\mathrm{P}^{4}$ & IGF 9452V & Borro Strolla BS1 & 1.44 & & 1.44 & \\
$\mathrm{P}^{4}$ & IGF 9475V & Borro Strolla BS2 & 1.35 & 3.04 & 2.65 & 1.23 \\
$\mathrm{M}^{1}$ & IGF 9453V & Borro Strolla BS1 & 1.37 & 2.78 & 2.43 & 2.14 \\
$\mathrm{M}^{1}$ & IGF 9475V & Borro Strolla BS2 & 1.33 & 2.92 & 2.50 & 2.12 \\
$\mathrm{M}^{2}$ & IGF 9455V & Borro Strolla BS1 & 1.06 & 2.08 & 2.00 & 1.44 \\
$\mathrm{M}^{2}$ & IGF 9470V & Borro Strolla BS1 & 1.09 & $(1.87)$ & 1.71 & 1.46 \\
$\mathrm{M}^{2}$ & IGF 9475V & Borro Strolla BS2 & 1.23 & & & 2.06 \\
$\mathrm{P}_{3}$ & IGF 9434V & Velona & $(1.49)$ & & & \\
$\mathrm{P}_{3}$ & IGF 9435V & Velona & 1.74 & 1.63 & & \\
$\mathrm{P}_{3}$ & IGF 9469V & Borro Strolla BS1 & 1.84 & 1.79 & & \\
$\mathrm{P}_{3}$ & IGF 9454V & Borro Strolla BS1 & 1.18 & 1.08 & & \\
$\mathrm{~d}_{3}$ & IGF 9456V & Borro Strolla BS1 & 1.54 & 1.34 & & \\
\hline Prolagus aff. sorbinii & $L$ & $W$ & AA & PH \\
\hline $\mathrm{P}^{2}$ & NMB FP 29 & Arcille & 1.24 & 1.97 & & \\
$\mathrm{P}^{3}$ & NMB FP 29 & Arcille & 1.68 & & 2.05 & \\
$\mathrm{P}^{4}$ & NMB FP 29 & Arcille & 1.35 & 2.81 & 2.58 & 1.34 \\
$\mathrm{M}^{1}$ & NMB FP 29 & Arcille & 1.42 & 2.56 & & \\
$\mathrm{M}^{2}$ & NMB FP 29 & Arcille & 1.29 & & & \\
$\mathrm{P}_{3}$ & IGF 1061V & Arcille & 2.52 & 2.78 & & \\
$\mathrm{P}_{3}$ & NMB FP 30 & Arcille & 2.16 & 2.39 & & \\
$\mathrm{P}_{3}$ & NMB VA 2246 & Case Inferno & 2.22 & 2.23 & & \\
\hline
\end{tabular}

\begin{tabular}{llllllll}
\hline Alilepus meini & $L$ & $W$ & AA & PH & Ltrig & Wtrig & Wtal
\end{tabular}

\begin{tabular}{lllllllll}
\hline $\mathrm{P}^{4}$ & NMB BAC 1064 & BCB V3 & 2.12 & & & & & \\
$\mathrm{M}^{1(?)}$ & NMB BAC 1063 & BCB V3 & 1.97 & 3.55 & 2.22 & & & \\
$\mathrm{M}^{\#}$ & NMB BAC 1061 & BCB V3 & & & & & & \\
$\mathrm{P}_{4}$ & NMB BAC 1062 & BCB V3 & 2.66 & & 1.36 & 3.34 & 2.55 \\
$\mathrm{M}_{1}$ & NMB BAC 1073 & BCB V3 & & & & 3.00 &
\end{tabular}

\begin{tabular}{llll}
$\mathrm{M}_{1}$ & $\mathrm{NMB}$ BAC 1073 & $\mathrm{BCB}$ V3 & 3.00 \\
\hline
\end{tabular}

\begin{tabular}{lllll}
\hline Trischizolagus sp. & & \multicolumn{2}{l}{$W$} \\
\hline $\mathrm{M}^{2}$ & IGF 9468V & Borro Strolla BS1 & 1.17 & \\
$\mathrm{D}_{3}$ & IGF 9464V & Borro Strolla BS1 & 1.87 & 1.5 \\
$\mathrm{P}_{3}$ & IGF 9467V & Borro Strolla BS1 & 1.69 & 1.56 \\
\hline \multicolumn{2}{l}{ Oryctolagus valdarnensis } & $L$ & $W$ \\
\hline $\mathrm{P}^{2}$ & IGF 946 (sx) & Castello dell'Incisa & 2.40 & 4.98 \\
$\mathrm{P}^{2}$ & IGF 946 (dx) & Castello dell'Incisa & 2.45 & 5.02 \\
$\mathrm{P}^{2}$ & IGF 10130 (sx) & Upper Valdarno & 2.45 & 4.76 \\
$\mathrm{P}^{2}$ & IGF 10130 (dx) & Upper Valdarno & 2.49 & 4.80 \\
$\mathrm{P}_{3}$ & IGF 246V & Case Inferno & $(3.33)$ & \\
$\mathrm{P}_{3}$ & IGF 952 & Le Strette al Tasso & $(2.90)$ & \\
$\mathrm{P}_{3}$ & IGF 10129 & Upper Valdarno & 4.10 & 4.07 \\
$\mathrm{P}_{3}$ & IGF 12741 & Upper Valdarno & 4.00 & 4.10 \\
$\mathrm{P}_{3}$ & NMB VA 1798 & Tasso & 3.19 & 3.30 \\
$\mathrm{P}_{3}$ & NMB VA 2009 & Case Inferno & 3.40 & 3.12
\end{tabular}

the p3 from Velona the centroflexid is considerably deeper. The metaisthmus is relatively wide, whereas the protoisthmus is thinner. The protoconulid is variable.
In general it can be stated that IGF $9434 \mathrm{~V}$ from Velona is more similar to IGF $9469 \mathrm{~V}$ from Borro Strolla than to other $\mathrm{P}_{3}$ from Velona.

\section{Results}

We ascribe Prolagus from Borro Strolla to $P$. cf. sorbinii because in spite of showing the main characters that distinguish $P$. sorbinii (e.g.: $\mathrm{P}_{3}$ with continuous enamel on the thick entoconid; $\mathrm{D}_{3}$ with accessory labial cusp; $\mathrm{P}^{3}$ with right-angled connection between lagicone and lagiloph, and centrocone not reaching the labial edge of the tooth; $\mathrm{P}^{4}$ with relatively short and $\mathrm{V}$-shaped hypoflexus, very long and verticalized parafossette; $\mathrm{M}^{1-2}$ with fossettes; Angelone 2007) it shows some peculiar traits. Actually in the specimens from Borro Strolla the overall shape of $\mathrm{P}_{3}$ is more elongated, the anteroconid is not indented, the entoconid less prominent, the mesoflexus very wide, giving to the metaconid a peculiar triangular shape, the centroflexid is shorter; in $\mathrm{D}_{3}$ the connection between trigonid and talonid lobe is not present; constant presence in $\mathrm{M}^{1-2}$ of two fossettes.

The dimensions of $P$. cf. sorbinii from Borro Strolla are slightly smaller than those of "classic" $P$. sorbinii (Angelone 2007) (Fig. 4a).

Prolagus cf. sorbinii from Velona had already been analyzed in Angelone (2007) and we confirm here its systematic attribution. Its small size and the slender $\mathrm{P}_{3}$ with triangular metaconid differentiate it from $P$. sorbinii and make it resemble to $P$. cf. sorbinii from Borro Strolla.

We redescribe here $P$. cf. sorbinii from Velona because its morphology was incorrectly drawn in Angelone (2007; cfr. fig. 3a-d and fig. 4a-d, p. 411 in the cited paper). We provide new pictures and references to inventory numbers, lacking in Angelone (2007).

Prolagus aff. sorbinii Masini, 1989.

Figure $3 \mathrm{~m}-\mathrm{t}$, measures in Table 1.

1935 “....rechtsseitiges Mandibelfragment von Prolagus...Basler Naturhistorisches Museums” Tobien, p. 307.

1972 Prolagus sardus sardus Fondi, pl. II, fig. 13.

1976 Prolagus sp. Hürzeler and Engesser, p. 336.

1990 Prolagus gr. michauxi-calpensis/savagei Rook and Masini, p. 357, II col., line 16 on; p. 358, fig. 1b; p. 358, tab. 1.

1990 Prolagus sp. Rook and Masini, p. 357, II col., line 9 on; p. 358 , fig. 1a; p. 358, tab. 1.

1992 Prolagus gr. capensis/savagei (sic) Sala, p. 212-213. 1994 Prolagus sp. Masini et al., p. 382.

1996 Prolagus gr. michauxi-calpensis/savagei Torre et al., p. 562 . 


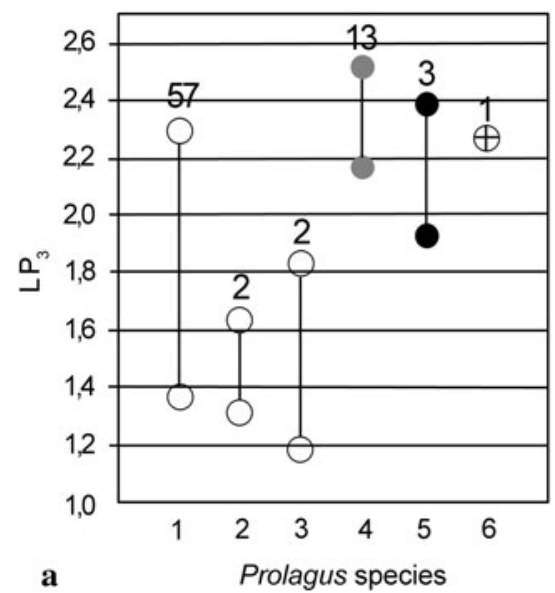

Fig. 4 a Comparisons of $\mathrm{P}_{3}$ length $\left(\mathrm{LP}_{3}\right.$, in $\left.\mathrm{mm}\right)$ of Italian species of Prolagus: 1 P. sorbinii (Brisighella 25), 2 P. cf. sorbinii (Velona), $3 P$. cf. sorbinii (Borro Strolla), 4 P. italicus (Montagnola Senese + Torre Picchio), 5 Prolagus aff. sorbinii (Arcille), 6 "P. savagei" (Arondelli), (data from Angelone 2007, 2008 and C.A. personal database). b Comparisons of $\mathrm{LP}_{3}$ of Late Pliocene-

2003 Prolagus gr. P. michauxi-P. calpensis Kotsakis et al., p. 319 , fig. 5d; p. 338 .

Localities: Arcille (Late Pliocene, Grosseto district), Solava (Early Pleistocene, late Villányian, Upper Valdarno Basin) and Case Inferno (Early Pleistocene, Early Biharian, Upper Valdarno Basin).

Age: Late Pliocene-late Early Pleistocene.

\section{Material}

Arcille: upper jaw sin: NMB FP29 (broken, only tooth row); lower jaw sin: NMB FP30 (broken, with $\mathrm{P}_{3}-\mathrm{M}_{1}$ ); lower jaw dx: NMB 1601V (broken, with $\mathrm{M}_{1}$ and loose $\mathrm{P}_{3-4}$ and $\mathrm{M}_{2}$ ).

Solava: lower jaw sin: IGF 2827V (broken, with $\mathrm{P}_{4}-\mathrm{M}_{2}$ ). Case Inferno: lower jaw dx: NMB VA2246 $\left(\mathrm{P}_{3}-\mathrm{M}_{2}\right)$.

\section{Description}

Lower jaw: (Fig. 3m) on the jaw fragments IGF $1601 \mathrm{~V}$ and IGF $2827 \mathrm{~V}$ is still visible a large, round or oval posterior mandibular foramen lying in a very low position (just next to the jaw lower border) and under the anterior part of $\mathrm{m}_{1}$. NMB VA2246 is well preserved, but it is mounted on its support with wax, thus the observation of the foramina has not been possible. NMB FP30 is too damaged to provide useful information

$\mathrm{P}^{2}$ : (Fig. 3p) elongated shape, broken in distal lingual side; long mesial hyperloph with enamel hiatus; elongated lagiloph; equally deep mesoflexus and paraflexus; the paraflexus is slightly widened ant the distal end).

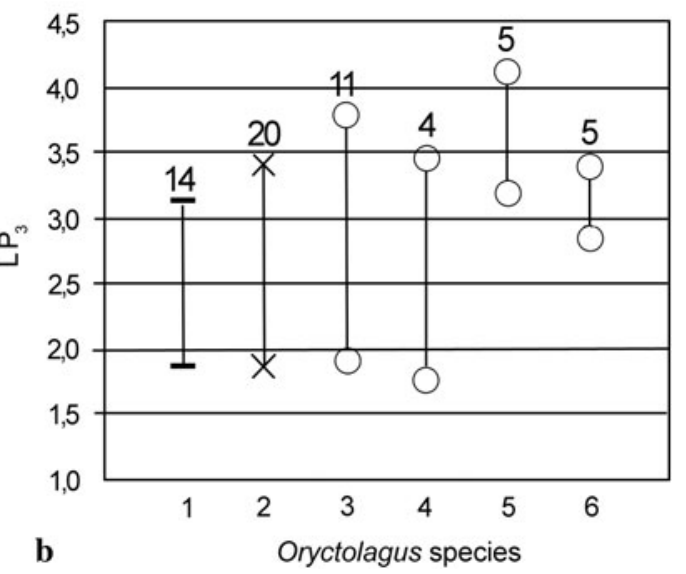

Early Pleistocene primitive European species of Oryctolagus: 1 O. laynensis (Layna, Spain), 2 O. cf. lacosti (La Escala, Spain), 3-6 O. valdarnensis from Montagnola Senese (3), Torre Picchio (4), Upper Valdarno, Tasso FU (5) and Pirro Nord (6); (data from López Martínez 1989, Angelone 2012, and C.A. personal database). The number on top of size ranges is the number of specimens

$\mathrm{P}^{3}$ : (Fig. 3q) mesial hyperloph with enamel hiatus; lagiloph reaching the labial edge of the tooth; connection lagiloph-centrocone marked by a "step".

$\mathrm{P}^{4}$ : (Fig. 3r) distal hyperloph longer than mesial one; U-shaped, deep hypoflexus (about 50\% of the tooth length); anterior labial part of the parafossette very long and oblique; C-shaped mesofossette.

$\mathrm{M}^{1-2}$ : (Fig. 3s, t) very deep, posteriorly curved hypoflexus; in $\mathrm{M}^{1}$ just posteriorly of the hypoflexus is present a large, elongated, oval fossette.

$\mathrm{P}_{3}$ : (Fig. 3n, o) triangular, lingually indented anteroconid, as large as metaconid; triangular metaconid, separated from the entoconid in IGF $1601 \mathrm{~V}$; deep, U-shaped and posteriorly curved mesoflexid (confluent in the centroflexid in IGF 1601V); thick entoconid, without enamel hiatus; wide metaisthmus (absent in IGF 1601V); protoisthmus variable in width; relatively small protoconid; large protoconulid, especially in NMB FP30 and NMB VA2246; long, undulated centroflexid, curved towards the labial side of the tooth.

Results

Prolagus remains from Arcille and Case Inferno are indeed scanty and separated by about 1,4 Ma. However, their $\mathrm{P}_{3}$ look very alike. The only difference is that (as should be expected) some characters appear in a slightly more advanced stage in the younger specimen, the one from Case Inferno (e.g., the anteroconid labial indentation is deeper, the protoconid is thinner, the protoconulid is more robust). The lower jaw from Solava lacks its most diagnostic element, the $\mathrm{P}_{3}$. However, the fact that it has been found in the Upper Valdarno and the position 
of the posterior mandibular foramen similar to the jaw from Arcille, allow us to tentatively assign it to $P$. aff. sorbinii.

The $\mathrm{P}_{3}$ of Prolagus from Arcille and Case Inferno look almost identical to " $P$. savagei" (NW Italy, almost coeval to Arcille; Berzi 1967) and P. depereti (Perpignan, Early Pliocene, MN14; López Martínez and Thaler 1975): in all these species we observe $L \approx W$, absence of the crochet, indented anteroconid, oblique centroflexid, developed protoconulid, thick entoconid and similar dimensions. This means that they should all be grouped under " $P$. savagei" that has nomenclatorial priority. However, "P. savagei" was reputed an invalid species (López Martínez and Thaler 1975), a decision contested by Azzaroli (1977). Eventually " $P$. savagei" was put in synonymy with $P$. calpensis (López Martínez in Alberdi et al. 1997). In our opinion $P$. calpensis shows characters that are incompatible with the specimens from Tuscany here analyzed and with those of NW Italy (e.g., thin entoconid with enamel hiatus, not indented anteroconid). This nomenclatorial confusion can be settled only after a revision of the mentioned species.

Therefore, as the Prolagus remains from Arcille and Case Inferno show some morphological characters in common with the well-characterized species $P$. sorbinii (Messinian-Early Pliocene, MN13-MN14; Angelone 2007), we prefer for the moment to classify them as Prolagus aff. sorbinii. This ascription also underlines their possible phylogenetic relationship with $P$. sorbinii. Prolagus aff. sorbinii shares with $P$. sorbinii: $\mathrm{P}_{3}$ with a bent centroflexid, thickened entoconid without enamel hiatus, and indented anteroconid; $\mathrm{P}^{4}$ with an anteriorly bent, long parafossette; $\mathrm{M}^{1}$ retaining one oval fossette (uncommon but observed in P. sorbinii). It is also very remarkable the similarity of the post-anteroconid morphology of Prolagus aff. sorbinii with juvenile P. sorbinii, in which the crochet is absent and the metaconid is often isolated. However, contrarily to $P$. sorbinii, in $P$. aff. sorbinii the $\mathrm{P}_{3}$ does not bear a crochet, the triangular anteroconid is larger and more flattened, the protoconid is smaller and the protoconulid is thicker; the $\mathrm{P}^{2}$ has enamel hiatus; the $\mathrm{P}^{4}$ does not have a $\mathrm{V}$-shaped hypoflexus; there is no fossette on $\mathrm{M}^{2}$; moreover, the $\mathrm{P}_{3}$ dimensions are quite larger in $P$. aff. sorbinii.

Another species closely related to $P$. sorbinii is $P$. italicus of the Early Pleistocene (MN17) of central Italy (Angelone 2008). The tooth morphology of P. italicus is very different from Prolagus aff. sorbinii. The most blatant difference is the crenulated enamel band of the former; moreover, the $\mathrm{P}_{3}$ of $P$. italicus almost always bears a crochet $(>90 \%)$ in adult individuals, an additional indentation is present in the posterior part of the anteroconid and the centroflexid is straight.
Family Leporidae Fischer De Waldheim, 1817

Genus Alilepus Dice, 1931

Alilepus meini Angelone and Rook, 2011

Figure 5a, b; Table 1

1976 Leporidé aff. Hypolagus Hürzeler and Engesser, p. 335.

1983 aff. Hypolagus sp. De Giuli et al., p. 325.

1986 Leporid aff. Hypolagus Azzaroli et al., p. 215.

1989 Leporidae cf. Hypolagus sp. Rook 1989, p. 62.

1992 Alilepus sp., Rook, p. 142.

1992 cf. Hypolagus Rook, p. 142.

1995 Alilepus sp. Rook and Torre, p. 380.

1996 Alilepus sp. Rook et al., p. 5, Table 1.

1996 Leporidae aff. Hypolagus Rook et al., p. 5., tab. 1.

1997 Leporidae aff. Hypolagus sp. Kotsakis et al., p. 437.

1997 Alilepus sp. Kotsakis et al., p. 437.

1999 Alilepus sp. Rook et al., p. 199, tab. 10.3.

1999 aff. Hypolagus Rook et al., p. 199, tab. 10.3.

2003 Alilepus sp. Fladerer and Fiore, p. 54.

2004 Alilepus sp. Rook and Martínez-Navarro, p. 720.

2011 Alilepus meini Angelone and Rook, p. 153, fig. 2.

Locality: the material here analyzed has been collected by NMB team from an unrecorded locality referrable to level V3 of Baccinello. The type locality of the species is Ribardella (also reported as Ribaldella; cfr. Bernor et al. 2011) and additional material comes from Caprarecce, two of the several fossil-bearing localities of Baccinello V3 in the area of Melacce stream, south of Cinigiano (Angelone and Rook 2011; Bernor et al. 2011).

Age: Early Messinian.

Material: $\mathrm{P}^{4} \mathrm{dx}$ : NMB BAC1064; $\mathrm{M}^{1 ?} \mathrm{dx}$ : NMB 1063; upper molariform dx: NMB BAC 1061; $\mathrm{P}_{4}$ sin: NMB 1062; $\mathrm{M}_{1} \mathrm{dx}$ : NMB BAC 1073.

\section{Description}

$\mathrm{P}^{4}$ : (Fig. 5a) broken in the posterior lingual part, preventing width measurements; distal hyperloph longer than mesial one; hypoflexus very deep (about $75 \%$ of $W$ ), wide in its central and labial parts, highly crenulated in the mesial part, less crenulated in the distal one.

Upper molariforms: both damaged in the labial posterior part; it is difficult to estimate the lobe proportions and the hypoflexus depth; however, the hypoflexus does not seem as deep as in $\mathrm{P}^{4}$ and does not widen labially; the hypoflexus is more crenulated in the distal part with respect to the mesial one in $\mathrm{M}^{1 \text { ? }}$, whereas it is less crenulated in the mesial than in the distal part in the other upper molariform. 


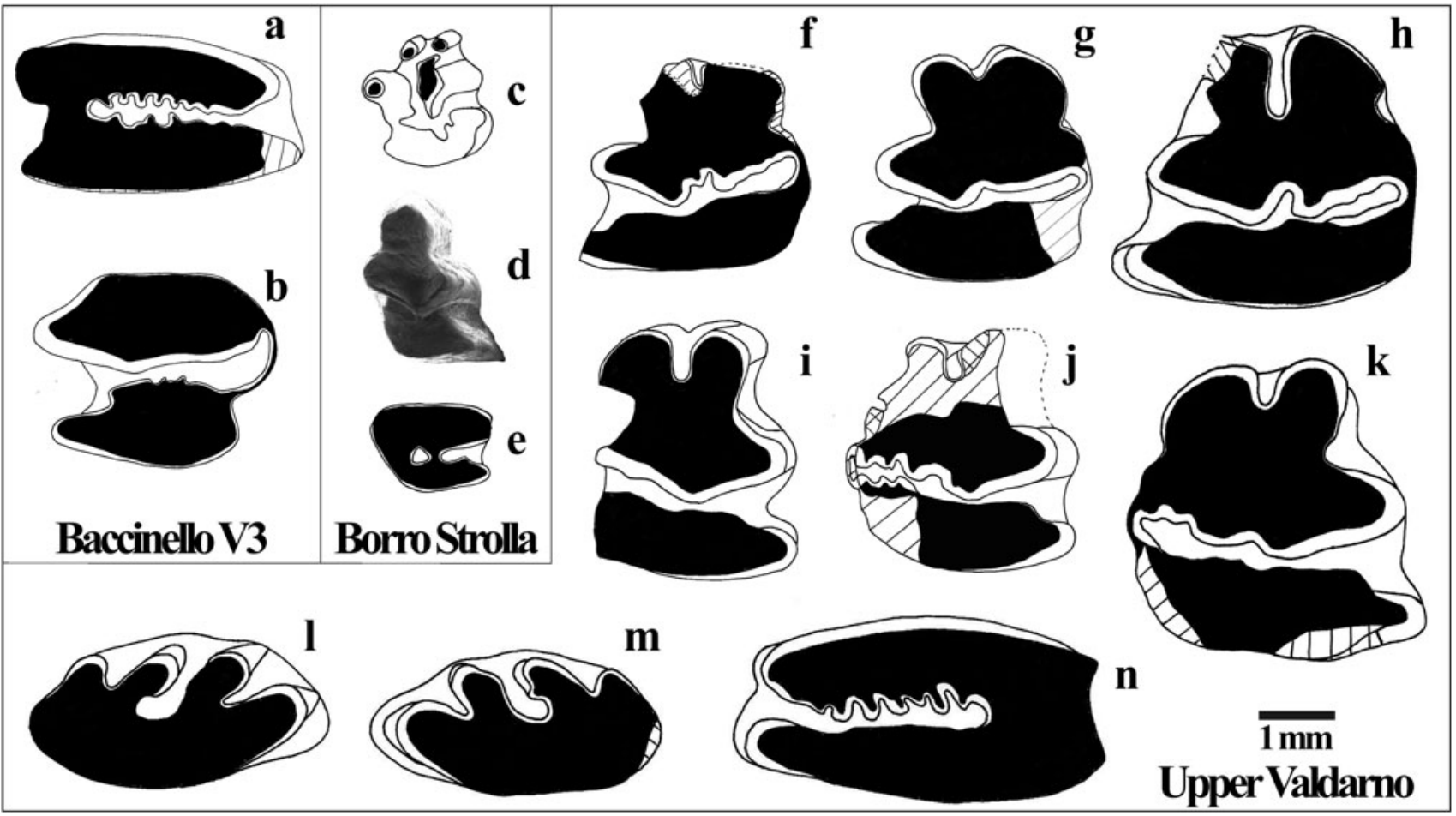

Fig. 5 a $\mathrm{P}^{4} \mathrm{dx}$ NMB 1064, Baccinello V3; b $\mathrm{P}_{4} \sin \mathrm{NMB} 1062$, Baccinello V3. Trischizolagus sp.: c $\mathrm{P}_{3}$ dx IGF 9467V; d $\mathrm{D}_{3} \mathrm{dx}$ IGF $9464 \mathrm{~V}$; e $\mathrm{M}^{2} \mathrm{dx}$ IGF $9468 \mathrm{~V}$. Oryctolagus valdarnensis: $\mathbf{f}-\mathbf{h} \mathrm{P}_{3} \sin$

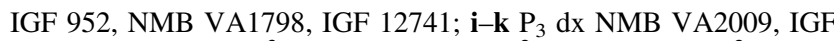
246V, IGF 10129; I P $\mathrm{P}^{3} \sin$ IGF 10130; $\mathbf{m} \mathrm{P}^{2}$ sin IGF 946; n $\mathrm{P}^{2} \mathrm{dx}$ IGF 10130
Lower molariforms: $\mathrm{P}_{4}$ (Fig. 5b) is well preserved, whereas the $\mathrm{m} 1$ is broken in its anterior and posterior lingual parts; Ltrig = Ltal; the hypoflexid noticeably widens in its lingual part; the anterior side of talonid is crenulated, and a "step" (not a notch) is present in the talonid labial side.

\section{Results}

The leporid remains referable to Baccinello V3 curated in NMB do not include highly diagnostic dental positions at the species level as $\mathrm{P}_{3}$ and, in less extent, $\mathrm{P}^{2}$. However, we noticed that the following characters fit in the morphological features that characterize A. meini, a taxon typical of the Baccinello V3 faunal assemblage (Angelone and Rook 2011):

1. A peculiar labially enlarged hypoflexus of $\mathrm{P}^{4}$;

2. The crenulation of the talonids in lower molariforms;

3. The lower molariform dimensions.

As for upper teeth dimensions a direct comparison between the original material of A. meini $\left(\mathrm{a}^{3}\right.$ ) and the specimens of NMB (a $\mathrm{P}^{4}$ and other dental positions posterior to $\mathrm{P}^{3}$ ) is not possible. However, the size of NMB specimens is slightly smaller $(6-10 \%)$ than the $\mathrm{P}^{3}$ of A. meini. The morphological and dimensional characters of the Baccinello V3 leporids from NMB are therefore compatible with their ascription to A. meini.

Genus Trischizolagus Radulesco and Samson, 1967

Trischizolagus sp.

Figure $5 \mathrm{c}-\mathrm{e}$, measures in Table 1

2008 Leporidae: gen. et sp. indet. Abbazzi et al., p. 620, tab. 1. 2011 Trischizolagus Angelone et al., p. 97 (partim).

Locality: Borro Strolla (Valdelsa Basin, Siena), sub-synthem BS-1.

Age: latest Messinian.

Material: $\mathrm{M}^{2}$ dx: IGF 9468V; $\mathrm{D}_{3}$ dx: IGF 9464V; $\mathrm{P}_{3} \mathrm{dx}$ : IGF $9467 \mathrm{~V}$.

\section{Description}

$\mathrm{M}^{2}$ : (Fig. 5e) young specimen, the distal hyperloph is much smaller than the mesial one; the hypoflexus does not reach the half of the tooth, and bears a spur on the posterior side and posteriorly to it lies a large, triangular fossette.

$\mathrm{D}_{3}$ : (Fig. 5d) large anteroconid is connected to the trigonid on the labial side; the metaconid is prominent; the 
trigonid is connected by a thin isthmus to the talonid; both ento- and hypoconid are slightly undulated in their anterior side.

$\mathrm{P}_{3}$ : (Fig. 5c) almost unworn individual; the anteroconids are two isolated, round islets; also the metaconid is isolated; the protoconid is connected to the talonid by a thin bridge of unworn enamel. The "hypoflexid" has a complex outline, does not reach the lingual side and bends, connecting to the centroflexid. In the "radical" side the conids connected and anteroflexid, protoflexid, paraflexid and metaflexid are formed.

Results

The scanty and badly preserved specimens from Borro Strolla consist in unworn or deciduous teeth. It is not possible to make a reliable comparison of the $\mathrm{P}_{3}$ from Borro Strolla with other species, even observing the broken "radical" view because the depth of the flexids varies with wear. The $\mathrm{D}_{3}$ from Borro Strolla has been compared with $T$. cf. maritsae from Alcoy N and Caravaca (Spain, López Martínez 1989) and the leporid from Brisighella known in literature as T. cf. maritsae (Gallai and Rook 2011 and references therein; C.A. unpublished data). Its dimensions fall in the lower range of the species. Its large anteroconid and the prominent metaconid fit in the morphology of the material taken as comparison. The $\mathrm{M}^{2}$ with a fossette has been observed in large populations of Trischizolagus from Spain (C.A. personal database).

These comparisons do not allow taxonomical attribution at the specific level. The early age of the sample (Mio-Pliocene boundary) should exclude an attribution to T. dumitrescuae, an eastern European species known since the Early Pleistocene.

Genus Oryctolagus Lilljeborg, 1879

Oryctolagus valdarnensis (Weithofer, 1889)

Figure $3 \mathrm{f}-\mathrm{n}$, measures in Table 1.

1875 Lepus sp. Forsyth Major, p. 39-40.

1876 Lepus sp. Forsyth Major, p. 345.

1884 Lepus sp. Forsyth Major, p. 2.

1889 Lepus valdarnensis Weithofer, p. 55.

1899a Lepus valdarnensis Bosco, p. 97-101, pl. XII (II), figs. 3,5 .

1899a Lepus etruscus Bosco, 100-101, pl. XII (II), fig. 8.

1899b Lepus valdarnensis Bosco, p. 264 (specimens described at points $1:, 2:, 3$ ).

1899b Lepus etruscus Bosco, p. 264-265.

1899 Caprolagus valdarnensis Forsyth Major, p. 487.

1954 Oryctolagus lacosti Viret.
1971 Lepus valdarnensis Forteleoni, p. 36, fig. 1a, 2a, 2c, 3a-1, 5b, tab. Ia, tab. IIa-o.

1972 Oryctolagus cuniculus Fondi, p. 9; pl. II. figs. 1-7.

1980 Lepus valdarnensis Borselli et al., p. 258.

1984 Lepus sp. De Giuli and Torre, p. 123.

1986 "Lepus" etruscus De Giuli et al., p. 2.

1990 "Lepus" cf. etruscus De Giuli et al., p. 31.

1989 Lepus etruscus López Martínez, p. 217.

1989 Lepus valdarnensis López Martínez, p. 217.

1989 Oryctolagus lacosti López Martínez, p. 221, 229-230; p. 231, fig. 59.

1992 Lepus etruscus Sala, p. 213.

1992 Lepus valdarnensis Sala, p. 213.

1997 Oryctolagus gr. lacosti Gliozzi et al., fig. 2.

2003 Oryctolagus cf. O. lacosti Girotti et al., p. 89; p. 90, fig. $6 \mathrm{c}$.

2003 Oryctolagus lacosti Kotsakis et al., p. 337, 2nd column, line 33.

2003 Oryctolagus lacosti Kotsakis et al., p. 337, 2nd column, line 45.

2003 Oryctolagus cf. O. lacosti Kotsakis et al., p. 338, 1st column, line 9.

2003 Oryctolagus cf. O. lacosti Kotsakis et al., p. 338, 1st column, line 30.

2003 Oryctolagus cf. O. lacosti Kotsakis et al., p. 338, 2st column, line 3.

2003 Oryctolagus cf. O. lacosti Kotsakis et al., p. 338, 2nd column, line 21.

2009 Oryctolagus cf. O. lacosti Argenti and Kotsakis, p. 61 , fig. 3 .

2012 Oryctolagus aff. lacosti Angelone.

Type: maxillary IGF 946 in Weithofer (1889).

Emended diagnosis: very large size; palatine very reduced and anterior part of choanae enlarged as in $O$. lacosti; $\mathrm{P}^{2}$ with deep flexa and hooked loop in the labial side of the paraflexus; $\mathrm{P}_{3}$ with lingual anteroconid larger than lingual one, often globular labial anteroconid, V-shaped paraflexus, deep, U-shaped anteroflexid, frequent paraflexid.

Geographical distribution: peninsular Italy (Montagnola Senese, Torre Picchio, Upper Valdarno [Olivola FU, Tasso FU], Pietrafitta, Monte Argentario, Pirro Nord).

Chronological distribution: Late Villányan-Early Biharian (Early Pleistocene).

Material: maxillary: IGF 946; IGF 10130; lower jaw sin: NMB VA1798 (with $\mathrm{P}_{3}-\mathrm{M}_{3}$ ), IGF 947 (with $\mathrm{P}_{4}-\mathrm{M}_{3}$ ), IGF 952 (with $\mathrm{P}_{3}-\mathrm{M}_{2}$ ), IGF 12741 (with $\mathrm{P}_{3}-\mathrm{M}_{2}$ ); lower jaw dx: 
NMB VA2009 (with $\mathrm{P}_{3}-\mathrm{M}_{2}$ ), IGF 246V (with $\mathrm{P}_{3}-\mathrm{M}_{3}$ ), IGF 10129 (with $\mathrm{P}_{3}-\mathrm{M}_{1}$ ).

\section{Description}

Upper jaw: long palatal bridge with palatine very reduced; the anterior part ends at the height of the base of $\mathrm{P}^{2}$, whereas the posterior part reaches the posterior part of $\mathrm{P}^{4}$; anterior part of choanae wide, posterior part lost.

$\mathrm{P}^{2}$ : (Fig. 51-m) developed, V-shaped mesoflexus, deep paraflexus with hooked posterior labial edge; deep hypoflexus; lagicone slightly smaller and less prominent than mesial hypercone.

Upper molariforms: (Fig. 5n) the deep hypoflexus (about $70 \%$ of tooth width) is crenulated in its anterior part, and may be undulated in the distal one.

Lower jaw: number and position of foramina variable.

$\mathrm{P}_{3}$ : (Fig. 5f-k) long anteroconids; the labial anteroconid seems longer than the lingual one except in IGF 12741 (Fig. 5h) and NMB VA1798 (Fig. 5g); the lingual anteroconid is the widest of the two; anteroflexid deep, wide (from the half to the entire length of anteroconids), U-shaped (except in NMB VA1798, in which the anteroflexid is V-shaped in its anterior side and U-shaped in its distal end); in one specimen (IGF 952, Fig. 5f) it can be observed how the shape of anteroflexid changes through ontogeny, from $\mathrm{V}$-shaped to U-shaped; labial anteroconid smaller than lingual one, as large as metaconid; V-shaped, smooth protoflexid, that together with the long anteroflexid "squeezes" the base of the labial anteroconid that may appear globular; deep hypoflexid, from smooth to crenulated in the lingual part (after the centroflexid); centroflexid variable from deep and crenulated to absent (NMB VA2009, Fig. 5i); paraflexid always present, with cement visible at the occlusal surface height (IGF 12741 and NMB VA1798) or starting at a lower part of the tooth shaft; in the posterior part of the hypoflexid, under the centroflexid, the enamel band bends sharply (except in VA 2009) whereas in IGF 10129 it bears a small notch.

Results and comparisons

\section{Historical background and revalidation of $O$. valdarnensis (Weithofer 1889)}

The first reports of leporids from Upper Valdarno (attributed to Lepus sp.; Forsyth Major 1875, 1876, 1884) were followed by their ascription to a new species, $L$. valdarnensis (Weithofer 1889), eventually split in two species (L. valdarnensis and L. etruscus, plus postcranial remains referred to Lepus sp.; Bosco 1899a, b). Eventually Forsyth Major (1899) attributed all the Upper Valdarno leporid remains to the genus Caprolagus. Fifty years later Viret
(1954) recognized them as pertaining to Oryctolagus putting them in synonymy with the western European species $O$. lacosti. Such decision was followed since then in literature except by Forteleoni (1971), who attempted to revalidate the species but provided insufficient or wrong iconographic and morphological information, as already remarked by López Martínez (1989).

We agree to assign the Upper Valdarno leporids to the genus Oryctolagus. Indeed they show "leporine" characters: very large dental size, comparable to that of Lepus, palatal bridge with palatine bone very reduced and wide choanae (at least in the anterior part, the only that can be observed), length of $\mathrm{P}_{4}<\mathrm{M}_{2}$. However, the validity of the maxillary characters (discriminant of extant Lepus and Oryctolagus) also for the fossil record was questioned by Viret (1954). Actually the very peculiar rabbit $O$. lacosti (Early Pleistocene of southern part of western Europe, plus isolate findings in Hungary and Greece; López Martínez 1989, 2008) shows such "leporine" maxillary characters. O. valdarnensis also shares with some populations of $O$. lacosti a very large size and an overall morphology of $\mathrm{P}_{3}$ and $\mathrm{P}^{2}$ that may appear similar at a superficial glance. On the other hand, in spite of a recent revision of material from the type locality (De Marfá and Mein 2007), O. lacosti is far from being a well-characterized species, as reflected by its very broad variability.

In our opinion $O$. valdarnensis is a valid species, characterized by the exclusive, contemporaneous presence of the following characters:

1. $\mathrm{P}_{3}$ with anteroflexid deep (DC1) and parallel-sided (DC2), globular labial anteroconid (DC3), V-shaped protoflexus (DC4); according to Angelone (2012) the contemporaneous presence of these characters distinguished Oryctolagus from Pirro Nord and Torre Picchio from other species. It is necessary to remark that Angelone (2012) stated: "The most similar to Oryctolagus from Pirro Nord among OOP [= Older Oryctolagus populations] from which $\mathrm{P}_{3}$ is available or well figured is the sample from Torre Picchio, as they share some distinctive characters absent in other OOP." However, the direct observation of the material from Montagnola Senese and Upper Valdarno revealed that also this material shows such characters and that important details were not described nor correctly figured in the correspondent literature.

2. $\mathrm{P}^{2}$ with paraflexus hooked in its labial posterior side (here defined as DC5);

3. very large dental size, fairly the largest known for the genus (Fig. 4b).

The observations made in Angelone (2012) to distinguish the population of Pirro Nord (there left in open nomenclature as $O$. aff. lacosti, and here included in 
O. valdarnensis) from other congeneric species of the Pleistocene of Europe are valid for $O$. valdarnensis and we thus refer to Angelone (2012) for further details. However, the distinctive characters of $O$. valdarnensis from Upper Valdarno can be summarized as follows: (1) straight anteroflexid; (2) paraflexid with cement always present; and (3) largest size.

We ascribe to $O$. valdarnensis the Late Villányan-Early Biharian Italian populations of Oryctolagus (OOP in Angelone 2012): Montagnola Senese (Tuscany, Fondi 1972), Torre Picchio (Umbria, Girotti et al. 2003); Pietrafitta (Umbria, Argenti and Kotsakis 2009), Monte Argentario (Angelone et al. 2008) and Pirro Nord (Angelone 2012). The locality Monte Peglia (Umbria, late Early Biharian, Van der Meulen 1973) was not included in this revision as the material (kept at the Istituto Italiano di Paleontologia in Rome, IsIPU) is at present not available for study. Lacking direct observation, we prefer not to include for the moment in $O$. valdarnensis the fossils from Casa Sgherri (Tuscany, Marcolini et al. 2000) and the old collections of Upper Valdarno housed in the Montevarchi Museum, that could likely pertain to $O$. valdarnensis on a geographical and temporal basis. In Angelone (2012) Oryctolagus remains from Upper Valdarno are referred to Olivola FU on the basis of Forteleoni (1971) statements. According to the most recent revision of the Upper Valdarno stratigraphy (Fidolini et al. 2012; Ghinassi pers. com), the Upper Valdarno Oryctolagus specimens herein analyzed, including those studied by Forteleoni (1968, 1971) must be referred (when a locality indication is available in the old collections labels) to Upper ValdarnoTasso FU. The occurrence of $O$. valdarnensis within the Olivola FU is also most probable since (fide Forteleoni 1971), within the Montevarchi collections are housed specimens from "Le Mignaie", a site correlatable with Castelfranco di Sopra, the type locality for Mimomys pliocaenicus (Masini and Torre 1987) and thus Late Villányan (Olivola FU).

We decided to include IGF 952 (Fig. 5f) in $O$. valdarnensis (contra Bosco 1899a, who considers it a separate species under the name of $L$. etruscus), because in the anterior side of its $\mathrm{P}_{3}$ it can be observed how the anteroflexid changes with wear leading to the typical anteroconid-trigonid morphology of $O$. valdarnensis. NMB VA1798 (Fig. 5g) was the most problematic specimen due to its particular anteroflexid (compare specimens in Fig. 5). The presence in NMB VA1798 of features characteristic of $O$. valdarnensis as a large labial anteroconid, a V-shaped protoflexid and of features typical of $O$. valdarnensis from Upper Valdarno, as a deep paraflexid with cement, let us in favor to ascribe it to $O$. valdarnensis.

Finally, we prefer not to formally include the Upper Valdarno remains assigned to Lepus sp. by Bosco (1899a) in $O$. valdarnensis, although they may most probably be referred to $O$. valdarnensis. Actually they consist in postcranial material that has not been analyzed in this revision.

\section{Intraspecific variability of $O$. valdarnensis}

The material of $O$. valdarnensis is relatively abundant and most dental positions are represented, as well as a few mandibles, only in Montagnola Senese (MS) and Torre Picchio (TP). Some slight differences distinguish the Upper Valdarno remains here analyzed and those from MS and TP. The first is the lesser average size in both cases. With respect to those from Upper Valdarno, the upper molariforms from MS appear highly crenulated also in the posterior part of the hypoflexus. The $\mathrm{P}_{3}$ from MS show a more globular labial anteroconid (DC3), due to the labially shifted anteroflexid end (15\% of incidence in Upper Valdarno, $60 \%$ of worn individuals in MP) and the cement in the paraflexid is much less frequent in MS. It is worth mentioning that the anteroflexid of MS population is U-shaped (DC2) and not V-shaped as figured in Fondi (1972), in which the enamel proportions are also altered. In MS it is possible to observe two juvenile $\mathrm{P}_{3}$, both with open hypoflexus (as those of O. laynensis; López Martínez 1989) and in the younger of the two (unworn) the lingual anteroconid is isolated.

Open hypoflexus and isolated lingual anteroconid are characteristics of the single juvenile individual from TP. What makes the population of TP very peculiar is the retention of a fossette posterior to the hypoflexus in two loose upper molariforms, probably pertaining to the smallaged individual. In addition, in $\mathrm{P}_{3}$ from $\mathrm{TP}$ the hypoflexid is extremely deep, touching the lingual edge of the tooth, the anteroflexid is straight, but always very deep (whereas in Upper Valdarno the depth is more variable), deeper than in MS, and the paraflexid is absent or extremely reduced.

The Oryctolagus sample from Pirro Nord (PN) represents a minimal part of a huge collection that is still unavailable for study and may provide complete information about the whole appendicular skeleton of $O$. valdarnensis. In its morphological traits the sample from $\mathrm{PN}$ is very similar to those of TP, except for the occurrence in $2 / 5$ specimens of $\mathrm{P}_{3}$ from $\mathrm{PN}$ of a paraflexid (one of the two filled with cement), a more frequent centroflexid, shorter anteroconids, and an even longer hypoflexid that in some cases can be "open".

In the sole upper jaw from Pietrafitta (figured in Argenti and Kotsakis 2009) it is possible to observe a $\mathrm{P}^{2}$ with paraflexus "curl" and upper molariforms with very deep, crenulated hypoflexus, as in $O$. valdarnensis. The only difference with the Upper Valdarno material seems a shallower paraflexus. 
A single $\mathrm{P}^{2}$ collected in a karst infilling at Monte Argentario, preliminarily classified as Leporidae indet. (Angelone et al. 2008) is probably to be ascribed to $O$. valdarnensis, due to the paraflexus hooked end.

\section{Discussion and conclusions}

\section{Taxonomy}

The revision of fossil lagomorphs of the latest NeogeneEarly Pleistocene of Tuscany housed in the NMB and IGF allows to identify the following lagomorph genera: Prolagus, Alilepus, Trischizolagus, Oryctolagus.

\section{Prolagus}

This study evidences that a species of Prolagus, different from those up to now identified in peninsular Italy (P. sorbinii and $P$. cf. sorbinii during Messinian and Early Pliocene, and $P$. italicus during Early Pleistocene; Angelone 2007, 2008 and references therein), is present in the Plio-Pleistocene of Tuscany (Arcille, Solava, Case Inferno). It closely resembles $P$ depereti, " $P$. savagei" and juvenile $P$. sorbinii. At present we prefer to leave it in open nomenclature as $P$. aff. sorbinii due to the taxonomic controversies that involve "P. savagei" (see section "Systematic palaeontology").

Additional data on Italian Prolagus are given by the study of Prolagus cf. sorbinii from the earliest Messinian and earliest Pliocene of Tuscany (Velona and Borro Strolla). Velona records the oldest report of the genus in the Italian peninsula. Prolagus cf. sorbinii from Velona shows similar morpho-dimensional features to the neighboring but younger population of Borro Strolla, with the sample from Maramena (Greece, Mio-Pliocene boundary; de Bruijn 1995) and with P. sorbinii Brisighella 6 (central Italy, post-evaporitic Messinian).

Other reports of Prolagus from Tuscany in old literature are nowadays unknown in the examined collections, and are here quoted for completeness of this revision.

- The occurrence of Prolagus sp. in the Baccinello V3 fauna was reported on the basis of a tentative "dimensional" attribution of a single upper first incisor of quite small size (B. Engesser pers. com. in Rook and Masini 1990). As a matter of fact, such an attribution cannot be confirmed since no trace of the incisor was found in the collections of NMB.

- The most famous "missing Prolagus of Tuscany" is the so-called Prolagus elsanus (nomen nudum according to López Martínez and Thaler 1975). The original material from Casino, eventually lost, was neither illustrated nor described (Forsyth Major 1875; Rütimeyer 1876). Forsyth Major (1899) gave a short description of $P$. elsanus and Tobien (1935) hypothesized its relationship with P. sardus. However, Forsyth Major (1899, p. 460-461) mentioned that the $\mathrm{P}_{3}$ of Prolagus elsanus (indicated in the original text as " $\mathrm{P}_{2}$ ") bore a small posterior cusp, that he never observed in other species of the genus. We agree with López Martínez and Thaler (1975) who identified such cusp as a hypoconulid. The hypoconulid is not a feature of the genus Prolagus. Thus, the actual presence of Prolagus sp. in the Casino fossil assemblage, reported also in relatively recent papers (Rook 1992, table 1 and p. 145; Rook et al. 1999, tab. 10.3) is in all probability incorrect.

- Falconer (1868) reports Lagomys (=Prolagus) among the vertebrates of Upper Valdarno with no further reference. The presence of Lagomys (=Prolagus) is confirmed by Forsyth Major (in Stoppani 1872; see also Forsyth Major 1884) but not in later faunal lists of the vertebrates of Upper Valdarno (Forsyth Major 1875, 1876, 1884). In the above mentioned publications there is no reference to repository or inventory numbers thus we do not know if such specimens of Lagomys (=Prolagus) were lost or if their taxonomic assignment was reconsidered in later lists (actually in later lists the elimination of Lagomys coincide with the appearance of Lepus). Bosco (1899a, b) finds no trace of Lagomys mentioned by Falconer and Forsyth Major, but reports and describes two lower right molariforms of Lagomys probably pertaining to the same mandible collected from Upper Valdarno that the IGF acquired in 1887 . The specimens (cited also by Tobien 1935) are not figured and are probably lost.

\section{Alilepus}

In a recent paper Angelone and Rook (2011) described the Baccinello V3 leporid material from IGF, and recognized it as belonging to a new species named Alilepus meini. The analysis of the leporid material from Baccinello V3 from the NMB collections allows us to exclude the occurrence within the Baccinello V3 assemblage of the genus Hypolagus as reported in faunal lists since Hürzeler and Engesser (1976) (see synonymic list) and thus confirming our taxonomic conclusions based on more recently collected material housed in the IGF (Angelone and Rook 2011).

\section{Trischizolagus}

Borro Strolla is the second Italian report of this quite rare genus after Brisighella (Rook and Delfino 2004, and references therein). The genus possibly occurs also at Moncucco (NW Italy, post-evaporitic Messinian, Angelone 
et al. 2011), but the leporid from this locality still lacks a detailed study and a generic attribution.

The taxonomical attribution of the studied Trischizolagus material has not been possible at the species level, because the available sample (Borro Strolla) consists of badly preserved, unworn or juvenile teeth. A revision of the Italian record of the genus is in progress.

\section{Oryctolagus}

The leporids from Upper Valdarno have a very long story of taxonomic controversies.

We agree with Weithofer (1889), who first described them, that they deserve the rank of independent species but we disagree with their assignment to the genus Lepus. Contra Bosco (1899b), we recognize a single species, Oryctolagus valdarnensis (Weithofer 1889), being the remains classified as L. etruscus an extreme of the morphodimensional variability. Six distinctive features characterize the teeth of $O$. valdarnensis: DC1 (deep anteroflexid), DC2 (parallel-sided anteroflexid), DC3 (globular anteroconid), DC4 (V-shaped protoflexus); DC5 (hooked labial side of the paraflexus), and the largest dental size range up to now reported in the genus.

We assign to Oryctolagus valdarnensis the Upper Valdarno leporids and those from the Late Villányian-Early Biharian local faunas of Montagnola Senese, Torre Picchio, Pietrafitta, Monte Argentario and Pirro Nord. Lacking direct observation, for the moment we prefer a cautious solution and we prefer not to include in the species $O$. valdarnensis the fossils from Casa Sgherri (Lower Valdarno), Mignaie (Upper Valdarno) and Monte Peglia. It is likely that the leporids from Casa Sgherri and Mignaie are O. valdarnensis, due to their geographical and temporal localizations. In Monte Peglia the taxonomic framework is more complex (both Oryctolagus and Lepus remains were reported, even if probably from different levels; Van der Meulen 1973); Monte Peglia is the last Oryctolagus-bearing Italian locality before a temporal gap in the Italian fossil record of the genus Oryctolagus in the Late Biharian (Angelone 2012), coeval to the first reliable record of Lepus in Italy. Thus, Monte Peglia is it a key site to understand the history and the evolution of Italian leporids. Unfortunately the material is at present not available for study.

The reports of "L. valdarnensis" out of the Italian peninsula (Romania, Simionescu 1932; Macarovici 1978 and references therein) were incorrect as they pertain to Trischizolagus dumitrescuae (Radulesco and Samson 1967).

Evolutionary trends and palaeobiogeography

The characters of Prolagus cf. sorbinii from Velona and Borro Strolla are similar to the specimens from Maramena
(Greece, Mio-Pliocene boundary, de Bruijn 1995) and $P$. sorbinii Brisighella 6 (central Italy, post-evaporitic Messinian). These features, characterizing samples of Messinian age, can be considered as fluctuations around a "classic" morphotype probably driven by palaeoecological conditions.

It is interesting to notice the co-occurrence of Prolagus cf. sorbinii and Trischizolagus sp. from the same subsynthem (BS-1) at Borro Strolla referable to the latest Messinian (Abbazzi et al. 2008). A feature in common with other latest Messinian sites known in Itay, Brisighella and, possibly, Moncucco.

Prolagus aff. sorbinii shares with $P$. italicus three among four of characters typified for the $\mathrm{P}_{3}$ of Plio-Pleistocene species of Prolagus of the Italian peninsula that distinguish them from western European coeval species (Angelone 2008): a thick entoconid, no entoconid enamel hiatus, size enlargement. The fourth character, the enamel crenulation and the retention of crochet, observed in $P$. italicus but not in Prolagus aff. sorbinii should be eliminated from the list of typical characters of Italian Plio-Pleistocene Prolagus species. Actually enamel crenulation can be observed in some non-insular geographically restricted species of prolagids (Ptychoprolagus forsthartensis and, in a less extent, P. laynensis; Angelone 2005, see figures in Tobien 1975; López Martínez and Thaler 1975).

Evidently, Prolagus aff. sorbinii had a wider geographical distribution than P. italicus (known only from two sites in central Apennines; Angelone 2008). For the moment it is not possible to define it with certainty, but if Prolagus aff. sorbinii, "P. savagei" and $P$. depereti are all belonging to the same species, with a distribution that includes at least north-western and central Italy and southern France.

Alilepus meini is one of the several large and small mammal species of the Early Messinian of southern Tuscany with a geographically restricted range (see Angelone and Rook 2011 and references therein). The evolutionary tendencies in dental pattern of leporids in non-insular geographically restricted environments is not known, but at least for Alilepus it seems to parallelize that of some ochotonids (Angelone 2005, see above) as its teeth show more crenulated/undulated enamel with respect to widerranging species, not coupled to size increase.

As mentioned above, concerning Trischizolagus sp., a revision of the leporids of the late Messinian of Italy (Brisighella and Moncucco) is pending. At present it is not possible to have a firmer taxonomic attribution and, consequently, to delineate hypotheses on the evolutionary tendencies and temporal and geographical distribution of this taxon.

The geographical distribution of the leporid Oryctolagus valdarnensis is also limited to the Italian peninsula during 
the Late Villányian-Early Biharian. Its appearance in the time equivalent to the Costa San Giacomo FU (2.3-2.1 Ma according to Sala and Masini 2007, and Rook and Martínez-Navarro 2010) follows that of $O$. lacosti in western Europe ( $\approx 2.5 \mathrm{Ma}$; López Martínez 2008). In central Italy the distribution area of $O$. valdarnensis overlaps that of $P$. italicus (actually $O$. valdarnensis is present in both Montagnola Senese and Torre Picchio), and that of the younger samples of $P$. aff. sorbinii (Upper Valdarno). In southern Italy (Pirro Nord) O. valdarnensis is found together with Hypolagus, although Angelone (2012) casts doubts on their actual temporal co-existence.

The differences noticed among the populations of $O$. valdarnensis may be due to different factors. If we consider the Upper Valdarno examined specimen of Tasso FU as a composite "population", we notice temporal trends in $\mathrm{P}_{3}$ towards:

1. Elongation of the hypoflexid, leading to a "open" hypoflexid in some specimens of Pirro Nord, that represents the retention of a juvenile character observed in Montagnola Senese and Torre Picchio.

2. More detached, smaller labial anteroconid if compared to lingual one.

3. A higher incidence of an anteroflexid as long as the anteroconids, also due to the shortening of the anteroconids.

Other features, such as the incidence of centroflexid, do not follow a precise trend and may be controlled by local factors (environment or interaction with other species). The degree of crenulation of the lingual side of the hypoflexid, and the incidence of paraflexid seem to follow a geographical trend (Torre Picchio and Pirro Nord, placed in a more southern geographical position, both lack crenulation and paraflexid).

Acknowledgments We thank Loïc Costeur (Basel) for the opportunity to contribute this volume dedicated to Burkart Engesser and for his careful and patient editorial work. We are also indebted with him (in his role as curator of the NMB palaeontological collections) for access to material in his care. At the same time, we are obliged with Elisabetta Cioppi and Stefano Dominici (Geology and Palaeontology Section of the Natural History Museum, University of Florence) for access to collections and archives of the Geology and Palaeontology Section, Natural History Museum of the Florence University. We gratefully acknowledge Roberto Fondi (Università di Siena), Marco Pavia (Università di Torino) and Enrico Squazzini (Museo di Paleontologia ex Chiesa di San Tommaso, Terni) for access to comparative material crucial for this study. Our gratitude also goes to the revisors for their useful comments, to Dr. M. Kunkel ("Sapienza" University of Rome) who helped us with translations from German, and to Dr. S. Lo Mastro (Università Roma Tre) for performing the SEM images. For researches that resulted important background to this work, C.A. received support from the SYNTHESYS Project http://www.synthesys.info/, financed by European Community Research Infrastructure Action under the FP6 "Structuring the European Research Area" (Project: HU-TAF-3145). This paper is framed within a wider project on Late Neogene Vertebrate Palaeontology developed at the University of Florence (coordinator L.R.).

\section{Appendix 1}

List of fossil material included in $O$. valdarnensis (Weithofer 1889) in addition to NMB and IGF Upper Valdarno specimens mentioned in the "Systematic palaeontology" section.

\section{Montagnola Senese}

Repository: Coll. Fondi, Dipartimento di Scienze della Terra, Università di Siena (Italy); prefix: IGPS

Material: incisors 154, 154a, 154b, 155, 156, 157, 158, 158a, 158b; $\mathbf{P}^{2} 146,147,148,149,227$; upper molariforms 150,151, 152,153,164, 165, 166, 167, 168, 169 $174,179,225,226$, plus 25 (previously classified as Prolagus); lower jaws 174, 178 (a composite of two mandibles, the anterior one (178a) with $\mathrm{P}_{3}-\mathrm{M}_{1}$, the posterior one (178b) with $\left.\mathrm{M}_{1}-\mathrm{M}_{3}\right) ; \mathbf{P}_{\mathbf{3}} 170,171,172,173,175$, 176, 177, 177a; lower molariforms 159, 160, 161, 162, 163, plus 29, 31 and 32 (previously classified as Prolagus).

In the specimens figured in Fondi (1972, pl. II, figs.1-7) the inventory numbers of the following specimens is different: 173 is reported as 169 (now assigned to a lower jaw); 175 is reported as 174 (now assigned to a lower jaw).

Torre Picchio

Repository: Mostra permanente "ex Chiesa di San Tommaso", Terni.

Material: upper molariforms 6.4, 6.5, 6.6, 7.2, 8.2, 8.3, 9.3; $\mathbf{P}^{2} 8.1$; lower jaw $10.1 ; \mathbf{P}_{\mathbf{3}} 6.7,9.2,11.1$; lower molariform 6.8 .

Pietrafitta

Repository: ENEL Thermoelectric Station "Città di Roma", Pietrafitta.

Material: upper jaw 1907.

Monte Argentario

Repository: Dipartimento di Scienze della Terra, Università di Torino; prefix: PU.

Material: $\mathbf{P}^{2} 463$

Pirro Nord

Repository: Dipartimento di Scienze della Terra, Università di Torino; prefix: PU. 
Material: $\mathbf{P}^{\mathbf{2}} 126999$ (fissure 10F); $\mathbf{P}_{\mathbf{3}}$ 126993, 126994 (fissure 10A), 126995, 126997, 126996, 126998 (fissure 10F).

\section{References}

Abbazzi, L., Benvenuti, M., Ceci, M. E., Esu, D., Faranda, C., Rook, L., et al. (2008). The end of the Lago-Mare time in the SE Valdelsa Basin (Central Italy): interference between local tectonism and regional sea-level rise. Geodiversitas, 30(3), 611-639.

Aguirre, E., \& Pasini, G. (1985). The Plio-Pleistocene boundary. Episodes, 8, 116-120.

Alberdi, M. T., Cerdeño, E., López Martínez, N., Morales, J., \& Soria, M. D. (1997). La fauna villafranquiense de El Rincón-1 (Albacete, Castilla-La Mancha). Estudios Geológicos, 53, 69-93.

Albianelli, A., Magi, M., Mazzini, M., \& Napoleone, G. (2002). The Plio-Pleistocene boundary in the northern Apennine continental deposits as defined by the Faella magnetostratigraphic section in the upper Valdarno. Bollettino della Società Geologica Italiana, Vol Spec., 1(2), 473-479.

Angelone, C. (2005). Evolutionary trends in dental morphology of the genus Prolagus (Ochotonidae, Lagomorpha) in the Mediterranean islands. In Alcover, J.A., \& Bover, P. (Eds.), Proceedings of the International Symposium "Insular Vertebrate Evolution: the Palaeontological Approach". Monografies de la Societat d'Història Natural de les Balears, 12, 17-26.

Angelone, C. (2007). Messinian Prolagus (Ochotonidae, Lagomorpha, Mammalia) of Italy. Géobios, 40, 407-421.

Angelone, C. (2008). Prolagus italicus n. sp. (Ochotonidae, Lagomorpha, Mammalia) a new Pliocene species of peninsular Italy. Géobios, 41, 445-453.

Angelone, C. (2012). Fossil lagomorphs from Pirro Nord (Apulia, southern Italy). Palaeontographica Abteilung A (in press).

Angelone, C., Colombero, S., Esu, D., Giuntelli, P., Marcolini, F., Pavia, M., et al. (2011). Moncucco Torinese, a new postevaporitic Messinian fossiliferous site from Piedmont (NW Italy). Neues Jahrbuch für Geologie und Paläontologie Abhandlungen, 259, 89-104.

Angelone, C., Marcolini, F., Pavia, G., \& Pavia, M. (2008). Dati preliminari sul Pleistocene Inferiore del Monte Argentario (Grosseto): uccelli e micromammiferi. Abstracts "VIII Giornate di Paleontologia”, 66, Siena.

Angelone, C., \& Rook, L. (2011). Alilepus meini n. sp. (Palaeolaginae, Leporidae, Lagomorpha), a new leporid from the Early Messinian of Tuscany (central-western Italy). Géobios, 44, $151-156$.

Angelone, C., \& Sesé, C. (2009). New characters for species discrimination within the genus Prolagus (Ochotonidae, Lagomorpha, Mammalia). Journal of Paleontology, 83, 80-88.

Argenti, P., \& Kotsakis, T. (2009). The fossil remains of Soricidae and Leporidae (Mammalia) in the Lower Pleistocene of Pietrafitta (Perugia, Central Italy). Bollettino della Società Paleontologica Italiana, 48, 59-62.

Azzaroli, A. (1977). Observation à l'article de N. López Martínez et L. Thaler "Biogéographie, évolution et compléments à la systématique du groupe d'Ochotonidés Piezodus-Prolagus". Bulletin de la Societé géolique de France (7), XVII, 1975, 850-866. Comptes Rendus sommaires de la Societé géologique de France, 1, 45.

Azzaroli, A., De Giuli, C., Ficcarelli, G., \& Torre, D. (1986). Mammal succession of the Plio-Pleistocene of Italy. Memorie della Società Geologica Italiana, 31, 213-218.
Benvenuti, M., \& Degli Innocenti, D. (2001). The Pliocene deposits in the central-eastern Valdelsa Basin (Florence, Italy) revised through facies analysis and unconformity-bounded stratigraphic units. Rivista Italiana di Paleontologia e Stratigrafia, 107, 265-286.

Benvenuti, M., Papini, M., \& Rook, L. (2001). Mammal biochronology, UBSU and palaeoenvironment evolution in a post-collisional basin: evidence from the Late Miocene BaccinelloCinigiano basin in Southern Tuscany, Italy. Bollettino della Società Geologica Italiana, 120, 97-118.

Bernor, R. L., Fortelius, M., \& Rook, L. (2001). Evolutionary Biogeography and Paleoecology of the "Oreopithecus bambolii Faunal Zone" (late Miocene, Tusco-Sardinian Province). Bollettino della Società Paleontologica Italiana, 40, 139-148.

Bernor, R. L., Kaiser, T. M., Nelson, S. V., \& Rook, L. (2011). Systematics and Paleobiology of Hippotherium malpassii n. sp. (Equidae, Mammalia) from the latest Miocene of Baccinello V3 (Tuscany, Italy). Bollettino della Società Paleontologica Italiana, 50(3), 175-208.

Berzi, A. (1967). Lagomorphs from the type Villafranchian of Villafranca d'Asti (Italy). Giornale di Geologia, 35, 137-150.

Berzi, A., Michaux, J., Hutchinson, J. H., \& Lindsay, E. (1967). The Arondelli local fauna, an assemblage of small vertebrates from the Villafranchian stage near Villafranca d'Asti, Italy. Giornale di Geologia, 35, 133-136.

Borselli, V., De Giuli, C., Ficcarelli, G., \& Mazzini, M. (1980). Casa Frata: una località fossilifera del Villafranchiano Superiore presso Terranova Bracciolini (Arezzo) nel Valdarno Superiore. Bollettino della Società Geologica Italiana, 19, 254-258.

Bosco, C. (1899a). I roditori pliocenici del val d'Arno superiore. Palaeontographia Italica, 5, 84-104.

Bosco, C. (1899b). I roditori pliocenici del val d'Arno superiore. Atti della Reale Accademia dei Lincei, 5, 261-265.

Bossio, A., Costantini, A., Foresi, L., Mazzei, R., Monterforti, B., Salvatorini, G., et al. (1991). Notizie preliminari sul Pliocene del bacino del medio Ombrone e della zona di Roccastrada. Atti della Società Toscana di Scienze Naturali, A, 98, 259-269.

Bossio, A., Mazzei, R., Salvatorini, G., \& Sandrelli, F. (2001). Geologia dell'area compresa tra Siena e Poggibonsi ("Bacino del Casino"). Atti della Società Toscana di Scienze Naturali Memorie, serie A, 107, 69-85.

Cioppi, E., \& Dominici, S. (2011). Origin and development of the geological and palaeontological collections. In S. Monechi \& L. Rook (Eds.), Il Museo di Storia Naturale dell'Università di Firenze. Volume 3-Le collezioni geologiche e paleontologiche (pp. 19-55). Firenze: Florence University Press.

de Bruijn, H. (1995). The vertebrate locality Maramena (Macedonia, Greece) at the Turolian-Ruscinian boundary (Neogene). 11-Lagomorpha (Mammalia). Münchner Geowissenschaftliche Abhandlungen A, 28, 133-136.

De Giuli, C., Ficcarelli, G., Mazza, P., \& Torre, D. (1983). Confronto fra le successioni marine e continentali del Pliocene e Pleistocene inferiore in Italia e nell' area mediterranea. Bollettino della Società Paleontologica Italiana, 22, 323-328.

De Giuli, C., Masini, F., \& Torre, D. (1986). The late Villafranchian faunas in Italy: the Casa Frata Local Fauna (Upper Valdarno, Tuscany). Palaeontographia Italica, 74, 1-9.

De Giuli, C., Masini, F., \& Torre, D. (1990). The latest Villafranchian faunas in Italy: the Pirro Nord local fauna (Apricena, Gargano). Quartärpaläontologie, 8, 29-34.

De Giuli, C., \& Torre, D. (1984). A microfauna with Allophaiomys pliocaenicus from Gargano, southern Italy. Palaeontographia Italica, 73, 116-128.

De Marfá, R., \& Mein, P. (2007). Révision d'Oryctolagus lacosti (Lagomorpha, Mammalia) du Pliocène supérieur de Perrier (Auvergne, France). Comptes Rendus Palévol, 6, 327-334. 
De Terra, H. (1956). New approaches to the problem of man's origin. Science, 124, 1282-1285.

Engesser, B. (1983). Die jungteritären Klinsäuger des Gebietes der Maremma (Toskana, Italien. 1.Teil: Gliridae (Rodentia, Mammalia). Eclogae Geologicae Helvetiae, 76, 763-780.

Engesser, B. (1989). The Late Tertiary small mammals of the Maremma region (Tuscany, Italy). 2nd part: Muridae and Cricetidae (Rodentia, Mammalia). Bollettino della Società Paleontologica Italiana, 28, 227-252.

Engesser, B. (2000). Johannes Hürzeler's research on Oreopithecus and the story of the discovery of "Sandrone". Atti del Museo di Storia Naturale della Maremma, 18, 11-23.

Falconer, H. (1865). On the species of Mastodon and Elephant occurring in the fossil State in Great Britain. (Read, 1857). Quarterly Journal of the Geological Society, 13, 307-360; 21, 253-332.

Falconer, H. (1868). The fossil Bovidae, Cervidae, and Antilopidae of India. In Murchison C. (ed.), Paleontological memoirs and notes of the late Hugh Falconer "Fauna Antiqua Silvalensis", 1, 280-291, London.

Fejfar, O. (2001). The arvicolids (Rodentia, Cricetidae, Mammalia) from Arondelli-Triversa: a new look. Bollettino della Società Paleontologica Italiana, 40, 185-193.

Fidolini, F., Ghinassi, M., Magi, M., Papini, M., \& Sagri, M. (2012). The Plio-Pleistocene Upper Valdarno Basin (Central Italy): Stratigraphy and basin fill evolution. Italian Journal of Geosciences (in press).

Fladerer, F. A., \& Fiore, M. (2003). The Early Pleistocene insular hare Hypolagus peregrinus sp. nov. from Northern Sicily. Palaeontographia Italica, 89, 37-63.

Fondi, R. (1972). Fauna cromeriana della Montagnola Senese. Palaeontographia Italica, 38, 1-27.

Forsyth Major, C. I. (1875). Considerazioni sulla fauna dei mammiferi pliocenici e post pliocenici della Toscana. Atti della Società Toscana di Scienze Naturali, 1, 39-40.

Forsyth Major, C. I. (1876). Sul livello geologico a cui è d'ascriversi il così detto cranio dell'Olmo. Archivio per l'Antropologia e la Etnologia, 6, 336-347.

Forsyth Major, C. I. (1884). On the mammalian fauna of the Val d'Arno. Quarterly Journal of the Geological Society of London, $41,1-8$.

Forsyth Major, C. I. (1899). On fossil and recent Lagomorpha. Transactions of the Linnean Society of London., 2(7), 433-520.

Forsyth Major, C. I. (1902). Some jaws and teeth of Pliocene voles (Mimomys gen. nov.) from the Norwich Crag at Thorpe, and from the Upper Val d'Arno. Proceedings of the Zoological Society of London, 1, 102-107.

Forteleoni, G. (1968). La Lepre del Valdarno Superiore Lepus valdarnensis Weithhofer. "Laurea" degree in Geological Sciences, Unpublished dissertation, Università degli Studi di Firenze.

Forteleoni, G. (1971). The upper Valdarno lagomorph Lepus valdarnensis. Palaeontographia Italica, 37, 55-68.

Gallai, G., \& Rook, L. (2011). Propotamochoerus provincialis (Gervais, 1859) (Suidae, Mammalia) from the latest Miocene (late Messinian; MN13) of Monticino Quarry (Brisighella, Emilia-Romagna, Italy). Bollettino della Società Paleontologica Italiana, 50(1), 29-34.

Ghetti, P., Anadón, P., Bertini, A., Esu, D., Gliozzi, E., Rook, L., et al. (2002). The Early Messinian Velona basin (Siena, central Italy): paleoenvironmental and paleobiogeographical reconstructions. Palaeogeography, Palaeoclimatology, Palaeoecology, 187, $1-33$.

Ghinassi, M., Abbazzi, L., Esu, D., \& Gaudant, J. (2005). Facies analysis, stratigraphy and Palaeontology (Molluscan and vertebrates) in the Upper Pliocene sandy flood-basin deposits of the
Upper Valdarno Basin (Northern Apennines). Rivista Italiana di Paleontologia e Stratigrafia, 111, 463-483.

Ghinassi, M., Magi, M., Sagri, M., \& Singer, B. S. (2004). Arid climate $2.5 \mathrm{Ma}$ in the Plio-Pleistocene Valdarno Basin (Northern Apennines, Italy). Palaeogeography, Palaeoclimatology, Palaeoecology, 207, 37-57.

Gillet, S., Lorenz, H. G., \& Woltersdorf, F. (1965). Introduction à l'étude du Miocène supérieur de Baccinello (environs de Grosseto, Italie). Bulletin du Service de la Carte Géologique de Alsace et Lorraine, 18, 31-42.

Girotti, O., Capasso Barbato, L., Esu, D., Gliozzi, E., Kotsakis, T., Martinetto, E., et al. (2003). The section of Torre Picchio (Terni, Umbria, Central Italy): a Villafranchian site rich in vertebrates, molluscs, ostracods and plants. Rivista Italiana di Paleontologia e Stratigrafia, 109, 77-98.

Gliozzi, E., Abbazzi, L., Argenti, P., Azzaroli, A., Caloi, L., Capasso Barbato, L., et al. (1997). Biochronology of selected mammals, molluscs and ostracods from the middle Pliocene to the late Pleistocene in Italy. The state of the art. Rivista Italiana di Paleontologia e Stratigrafia, 103, 369-388.

Hürzeler, J., \& Engesser, B. (1976). Les faunes de mammifères néogènes du Bassin de Baccinello (Grosseto, Italie). Comptes Rendus de l'Academie des Sciences de Paris, Séries II, 283, 333-336.

Kotsakis, T., Abbazzi, L., Angelone, C., Argenti, P., Barisone, G., Fanfani, F., et al. (2003). Plio-Pleistocene biogeography of Italian mainland micromammals. Deinsea, 10, 313-342.

Kotsakis, T., Barisone, G., \& Rook, L. (1997). Mammalian biochronology in an insular domain: the Italian Tertiary faunas. In Aguilar, J.-P., Legendre, S., \& Michaux, J. (Eds.), Actes du Congrès BiochroM'97. Mémoires et Travaux de l'École Pratique des Hautes Études, 21, 431-441, Montpellier.

Lazzarotto, A., \& Sandrelli, F. (1977). Stratigrafia ed assetto tettonico delle formazioni neogeniche nel bacino del Casino (Siena). Bollettino della Società Geologica Italiana, 96, 747-762.

López Martínez, N. (1989). Revisión sistemática y biostratigráfica de los Lagomorpha (Mammalia) del Terciario y Cuaternario de España. Memorias Museo Paleontologia Universodad de Zaragoza, 3, 1-342.

López Martínez, N. (2008). The Lagomorph fossil record and the origin of the European rabbit. In P. C. Alves, N. Ferrand, \& K. Hackländer (Eds.), Lagomorph biology: evolution, ecology, and conservation (pp. 27-46). Berlin: Springer.

López Martínez, N., \& Thaler, L. (1975). Biogéographie, évolution et compléments à la systématique du groupe d'Ochotonidés Piezodus-Prolagus. Bulletin de la Societé géologique de France 17(7), 850-866

López Martínez, N., Likius, A., Mackaye, H. T., Vignaud, P., \& Brunet, M. (2007). A new Lagomorph from the Late Miocene of Chad (Central Africa). Revista Española de Paleontología, 22, $1-20$.

Lorenz, H. G. (1968). Stratigraphisches und mikropaläontologisches Untersuchungen des Braunkohlengebietes von Baccinello (Grosseto, Italien). Rivista Italiana di Paleontologia e Stratigrafia, 74, 147-270.

Macarovici, N. (1978). Sur la faune des mammiferes fossiles neozoiques de la Roumanie. Revue Roumaine de Geologie, Geophysique et Geographie, serie de Geologie, 22, 71-98.

Marcolini, F., Bonadonna, F. P., Kotsakis, T., Mazza, P., \& Zanchetta, G. (2000). Preliminary data on the microand macromammal remains from Casa Sgherri, Lower Valdarno (Tuscany, Italy). Bollettino della Società Paleontologica Italiana, 39, 243-252.

Martini, I. P., \& Sagri, M. (1993). Tectono-sedimentary characteristics of late Miocene-Quaternary extensional basins of the northern Apennines, Italy. Earth Sciences Review, 34, 197-233. 
Masini, F., Ficcarelli, G., \& Torre, D. (1994). Late Villafranchian ad the earliest Galerian mammal faunas from some intermontane basins of north-central Italy. Memorie della Società Geologica Italiana, 48, 381-389.

Masini, F., \& Torre, D. (1987). Review of the Villafranchian Arvicolids of Italy. Geologica Romana, 26, 127-133.

Maul, L., Masini, F., Abbazzi, L., \& Turner, A. (1998). The use of different morphometric data for absolute age calibration of some South- and Middle European arvicolid populations. Palaeontographia Italica, 85, 111-151.

McGowran, B., Berggren, B., Hilgen, F., Steininger, F., Aubry, M. P., Lourens, S., et al. (2009). Neogene and Quaternary coexisting in the geological time scale: the inclusive compromise. Earth Science Reviews, 96, 249-262.

Napoleone, G., Albianelli, A., Azzaroli, A., Bertini, A., Magi, M., \& Mazzini, M. (2003). Calibration of the Upper Valdarno basin to the Plio-Pleistocene for correlating the Apennine continental sequences. Il Quaternario, 16, 131-166.

Napoleone, G., Albianelli, A., Azzaroli, A., \& Mazzini, M. (2001). The Poggio Rosso locality calibrated to the end-Pliocene and its significance for dating the late Villafranchian mammal faunas of the Upper Valdarno, Central Italy. Rivista Italiana di Paleontologia e Stratigrafia, 107, 287-296.

Palacios, F., \& López Martínez, N. (1980). Morfología dentaria de las liebres europeas (Lagomorpha, Leporidae). Doñana. Acta Vertebrata, 7(1), 61-81.

Radulesco, C., \& Samson, P. (1967). Contribution à la connaissance du complexe faunistique de Malusteni-Beresti (Pléistocène inférieur), Roumanie I. Ord. Lagomorpha, Fam. Leporidae. Neues Jahrbuch für Geologie und Paläontologie, Monatshefte, 9, 544-563.

Rook, L. (1989). Il bacino fluvio-lacustre di Baccinello-Cinigiano (media val d'Ombrone, GR). "Laurea" degree in Geological Sciences, Unpublished dissertation, Università degli Studi di Firenze: 1-95.

Rook, L. (1992). Italian Messinian localities with vertebrate faunas. Paleontología i Evolució, 24(25), 41-147.

Rook, L., Abbazzi, L., Chesi, F., Delfino, M., Ferretti, M. P., \& Gallai, G. (2008). The Italian record of latest Miocene continental vertebrates. Bollettino della Società Paleontologica Italiana, 47, 191-194.

Rook, L., Abbazzi, L., \& Engesser, B. (1999). An overview on the Italian Miocene land mammal faunas. In J. Agustí, L. Rook, \& P. Andrews (Eds.), The evolution of Neogene terrestrial ecosystems in Europe (pp. 191-204). Cambridge: Cambridge University Press.

Rook, L., Croitor, R., Delfino, M., Ferretti, M., Gallai, G., \& Pavia, M. (2012). The Upper Valdarno Plio-Pleistocene vertebrate record: an historical overview, with notes on palaeobiology and stratigraphic significance of some significant taxa. Italian Journal of Geosciences (in press).

Rook, L., \& Delfino, M. (2004). I vertebrati fossili di Brisighella nel quadro dei popolamenti continentali del Mediterraneo durante il Neogene. Ravenna Studi e Ricerche, 10(1)(2003), 179-207.

Rook, L., \& Ghetti, P. (1997). Il bacino neogenico della Velona (Toscana Italia): stratigrafia e primi ritrovamenti di vertebrati fossili. Bollettino della Società Geologica Italiana, 116, 335-346.

Rook, L., Harrison, T., \& Engesser, B. (1996). The taxonomic status and biochronological implications of new finds of Oreopithecus from Baccinello (Tuscany, Italy). Journal of Human Evolution, 30, 3-27.

Rook, L., \& Martínez-Navarro, B. (2004). Viverra howelli n.sp., a new viverrid (Carnivora, Mammalia) from the BaccinelloCinigiano basin (latest Miocene, Italy). Rivista Italiana Paleontologia e Stratigrafia, 110(3), 719-723.
Rook, L., \& Martínez-Navarro, B. (2010). Villafranchian: The long story of a Plio-Pleistocene European large mammal biochronologic unit. Quaternary International, 219, 134-144.

Rook, L., \& Masini, F. (1990). Prolagus from the Upper Valdarno (faunal associations of the Olivola and Tasso Units, Late Villafranchian). Bollettino della Società Paleontologica Italiana, 29, 357-360.

Rook, L., Oms, O., Benvenuti, M., \& Papini, M. (2011). Magnetostratigraphy of the Late Miocene Baccinello-Cinigiano basin (Tuscany, Italy) and the age of Oreopithecus bambolii faunal assemblages. Palaeogeography, Palaeoclimatology, Palaeoecology, 305, 286-294.

Rook, L., Renne, P., Benvenuti, M., \& Papini, M. (2000). Geochronology of Oreopithecus-bearing succession at Baccinello (Italy) and the extinction pattern of European Miocene hominoids. Journal of Human Evolution, 39, 577-582.

Rook, L., \& Torre, D. (1995). Celadensia grossetana nov. sp., (Cricetidae, Rodentia) from the late Turolian Baccinello-Cinigiano basin (Southern Tuscany, Italy). Géobios, 28, 379-382.

Rütimeyer, L. (1876). Ueber Pliocen und Eisperiode auf bieden Seiten der Alpen: ein Beitrag zu der Geschichte der Thierwelt in Italien seit der Tertiärzeit. Basel, H. Georg (pp. 1-78).

Sala, B. (1992). I segni del tempo. Memoria delle origini ed icone del primordiale. Atti del corso di aggiornamento per il personale docente, ottobre-dicembre 1992 (pp. 209-227). Trento, Liceo Ginnasio "G. Prati".

Sala, B., \& Masini, F. (2007). Late Pliocene and Pleistocene small mammal chronology in the Italian peninsula. Quaternary International, 160, 4-16.

Simionescu, I. (1932). Les vertebres pliocene de Bereşti. Bulletin de la Societe Roumaine de Geologie, 1, 215-228.

Stoppani, C. (1872). Corso di Geologia. (507 pp.). Milano.

Tobien, H. (1935). Über die pleistozänen und postpleistozänen Prolagus formen Korsikas und Sardiniens. Berichte der Naturforschenden Gesellschaft zu Freiburg, 34, 253-344.

Tobien, H. (1975). Zur Gebißstruktur, Systematik und Evolution der Genera Piezodus, Prolagus und Ptychoprolagus (Lagomorpha, Mammalia), aus einigen Vorkommen im jüngeren Tertiär Mittelund Westeuropas. Notizblatt des Hessischen Landesamtes für Bodenforschung zu Wiesbaden, 103, 103-186.

Torre, D. (1985). Mimomys savini and Arvicola cantiana in the Upper Valdarno (Italy). Eclogae geologicae Helvetiae, 78, 715-718.

Torre, D., Abbazzi, L., Bertini, A., Fanfani, F., Ficcarelli, G., Masini, F., et al. (2001). Structural changes in Italian Late PliocenePleistocene large mammal assemblages. Bollettino della Società Paleontologica Italiana, 40, 303-306.

Torre, D., Albianelli, A., Bertini, B., Ficcarelli, G., Masini, F., \& Napoleone, G. (1996). Paleomagnetic calibration of Plio-Pleistocene mammal localities in Central Italy. Acta Zoologica Cracoviensia, 39, 559-570.

Torre, D., Ficcarelli, G., Masini, F., Rook, L., \& Sala, B. (1992). Mammal dispersal events in the early Pleistocene of western Europe. Courier Forschungsinstitut Senckenberg, 153, 51-58.

Van Couvering, J., Aubry, M. P., Berggren, W. B., Gradstein, F. M., Hilgen, F., Kent, D. V., et al. (2009). What, if anything, is Quaternary? Episodes, 32(2), 1-2.

Van der Meulen, A. (1973). Middle Pleistocene smaller mammals from the Monte Peglia, (Orvieto, Italy) with special reference to the phylogeny of Microtus (Arvicolidae, Rodentia). Quaternaria, 17, 1-144.

Viret, J. (1954). Le loess à bancs durcis de Saint-Vallier (Drôme) et sa faune de Mammifères villafranchiens. Nouvelles Archives du Muséum d'Histoire naturelle de Lyon, 4, 1-197.

Weithofer, K. A. (1889). Ueber die tertiären Landsaugethiere Italiens. Jahrbuch der kaiserlich-königlichen Geologischen Reichsanstalt, 39, 80-81. 